\title{
Late Devonian and Triassic basalts from the southern continental margin of the East European Platform, tracers of a single heterogeneous lithospheric mantle source
}

\author{
Françoise Chalot-Prat ${ }^{1, *}$, Petr Tikhomirov ${ }^{2}$ and Aline Saintot ${ }^{3,4}$ \\ ${ }^{1}$ Centre de Recherches Petrographiques et Geochimiques - Nancy University, BP20, 15 rue Notre Dame des \\ Pauvres, F-54501 Vandoeuvre-les-Nancy Cedex, France. \\ ${ }^{2}$ Geological Faculty of Moscow State University; Vorobiovy Gory, 117311 Moscow, Russia. \\ ${ }^{3}$ Vrije Universiteit, Instituut voor Aardwetenschappen, Tektoniek afdeling, De Boelelaan 1085, \\ $1081 \mathrm{HV}$ Amsterdam, Netherlands. \\ ${ }^{4}$ Geological Survey of Norway, N-7491 Trondheim, Norway. \\ *e-mail: chalot@crpg.cnrs-nancy.fr
}

\begin{abstract}
In Late Devonian and Early-to-Late Triassic times, the southern continental margin of the Eastern European Platform was the site of a basaltic volcanism in the Donbas and Fore-Caucasus areas respectively. Both volcanic piles rest unconformably upon Paleoproterozoic and Late Paleozoic units respectively, and emplaced during continental rifting periods some $600 \mathrm{~km}$ away from expected locations of active oceanic subduction zones.

This paper reports a comparative geochemical study of the basaltic rocks, and views them as the best tracers of the involved mantle below the Eastern European Platform. The Late Devonian alkaline basic rocks differ from the calc-alkaline Triassic basic rocks by their higher alkali-silica ratio, their higher $\mathrm{TiO}_{2}, \mathrm{~K}_{2} \mathrm{O}, \mathrm{P}_{2} \mathrm{O}_{5}$ and $\mathrm{FeO}$ contents, their higher trace element contents, a higher degree of fractionation between the most and the least incompatible elements and the absence of $\mathrm{Ta}-\mathrm{Nb}$ negative anomalies. These general features, clearly distinct from those of partial melting and fractional crystallization, are due to mantle source effects. With similar $\mathrm{Nd}$ and $\mathrm{Sr}$ isotopic signatures indicating mantle-crust mixing, both suites would originate from the melting of a same but heterogeneous continental mantle lithosphere (refertilized depleted mantle). Accordingly the $\mathrm{Nd}$ model ages, the youngest major event associated with mantle metasomatism occurred during Early Neoproterozoic times $(\sim 650 \mathrm{Ma})$.
\end{abstract}

\section{Introduction}

The southern margin of the Eastern European Platform is structurally divided into two main parts: the Sarmatia segment of the East European Craton and the Scythian Platform lying south of it (figure 1).

The Sarmatia cratonic area is formed by four or five Archean terranes, welded together at 2.3 and $2.1 \mathrm{Ga}$ (see Bogdanova et al 1996).
Episodes of rifting destabilized the subsequent platform regime of the East European Craton, the first during the Riphean (Meso- to Neoproterozoic) and the second during the Late Devonian. The latter created the large Pripyat-Dniepr-Donets intra-cratonic rift basin (Bogdanova et al 1996; Artemieva 2003).

The origin and nature of the Scythian Platform basement (figure 1) remain unclear. It is overlain by a quite thick Phanerozoic sedimentary

Keywords. Basalts; East European Platform; Late Devonian; Triassic; Donbas; Fore-Caucasus; geochemistry; geodynamics; geology. 


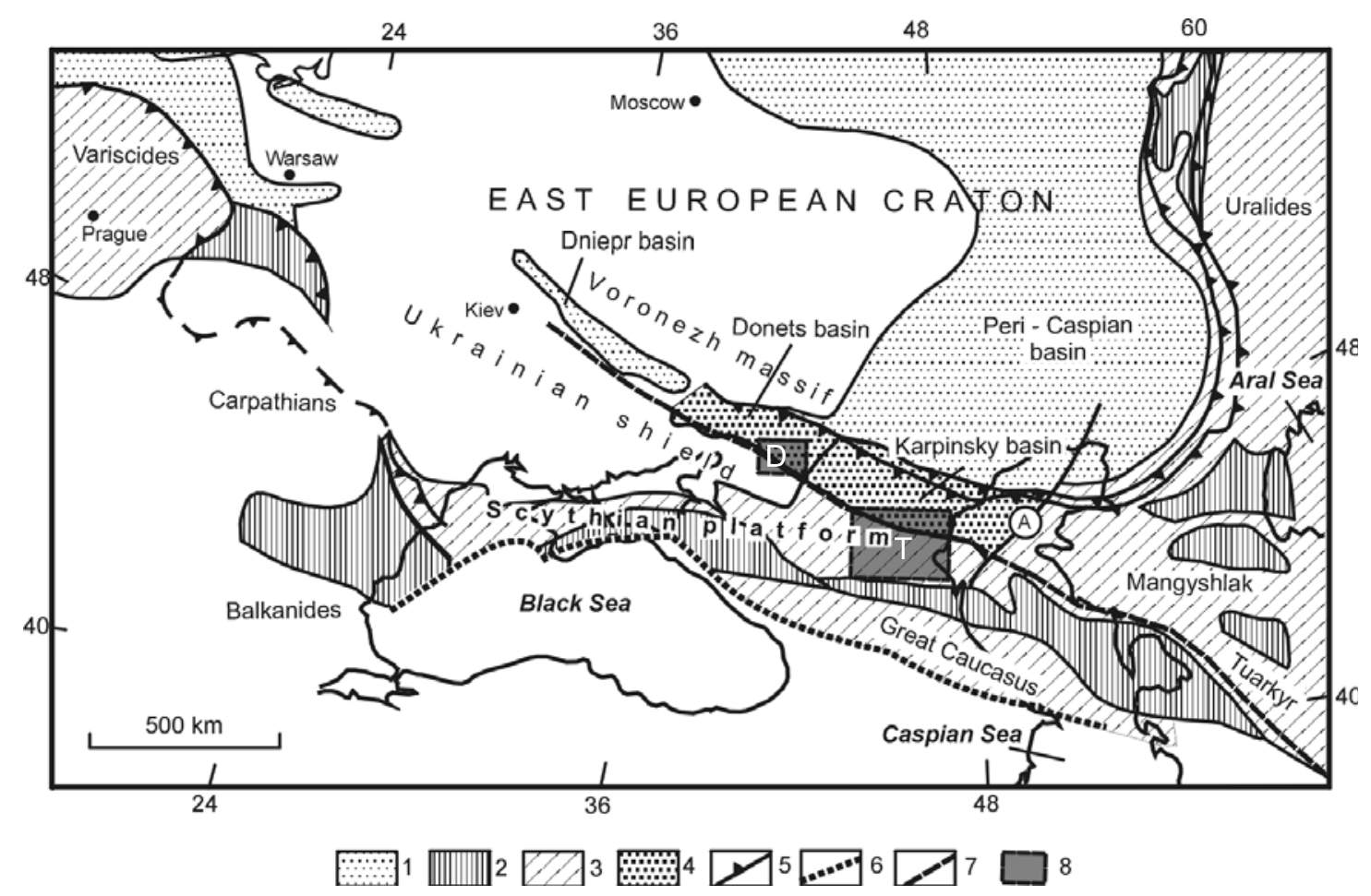

Figure 1. Late Paleozoic tectonic map of the southern East European craton and adjacent areas (modified after Tikhomirov et al 2004) in the hypothesis of a Variscan basement for the Scythian Platform (SP) (as for example in Zonenshain et al 1990). 1. Early Permian basins within the East European Craton; 2. Areas of Precambrian consolidation within the Late Paleozoic orogen; 3. Areas of Late Paleozoic consolidation; 4. Donets and Karpinsky basins, thought to be inverted during the Permian time; 5. Late Paleozoic and possibly younger thrusts; 6. Presumed shelf margin for the end of Permian; 7. Gissar-Donets fault zone; 8. Location of the Late Devonian (D) Donbas and Triassic (T) Fore Caucasus areas. A. Agrakhan-Guriev fault.

cover (locally more than $10 \mathrm{~km}$ thick). Geophysical data only allow characterizing the basement as few drill-holes reached at the deepest the Late Paleozoic succession. A classical model suggests that the Scythian Platform is part of the Late Variscan orogenic belt, between Western Europe and Urals (Arthaud and Matte 1977; Zonenshain et al 1990; Nikishin et al 1996 and presented as such on figure 1). However, no strong penetrative Late Paleozoic deformation is actually observed on the Scythian Platform. Another hypothesis to test is that the Scythian Platform was part of the Late Proterozoic Baikalian belt fringing Baltica (e.g., Saintot et al 2006). This Late Proterozoic orogenic event might have resulted from the amalgamation/accretion of subduction-related arc/oceanic complexes and micro-continental blocks (as the Beloretzk terrane along the Southern Proto-Urals, Glasmacher et al 1999; the Pechora-Barentsia terranes on the Timan-Pechora foldbelt, Nikishin et al 1996; see Torsvik and Rehnstrom 2001) along the margin of the present-day northern and eastern Baltica, without involving collision of large continental masses. The Scythian Platform, considered herein as part of the Late Proterozoic Baikalian belt, became a renewed passive margin affected by episodes of rifting during the Late Devonian, the Permo(?)-Triassic (Gaetani 2000), and further southwards, Jurassic (Lordkipanidze et al 1989; Nikishin et al 1998a, b) and Cretaceous (Nikishin et al 1998a, b).

Among the rift basins which formed on the Scythian Platform during Phanerozoic times (figure 1), five were accompanied by significant eruptions and/or sub-surface intrusions of mantlederived magma:

- the Late Devonian Dniepr-Donets-Donbas basin (Chekunor and Naumenko 1982; Wilson and Lyashkevich 1996; McCann et al 2003);

- the Triassic Eastern Fore Caucasus basin (Dubinski and Matsenko 1965; Burshtar et al 1973; Nazarevich et al 1986; Tikhomirov et al 2004);

- the Jurassic Western Fore Caucasus basin (Lordkipanidze et al 1989);

- the Cretaceous Karkinit rift basin (western part of Scythian Platform) (Muratov 1969; Chekunov et al 1976; Grigorieva et al 1981; Leschukh 1992; Nikishin et al 1998a, b, 2001);

- the Neogene Minvody basin (Stavropol High) (Polovinkina 1960; Adamia and Lordkipanidze 1989). 
The two volcanic suites and associated sediments of interest herein, of the Donbas and of the Eastern Fore-Caucasus, were deposited in quite similar tectonic settings. The Late Devonian event of the Donbas and the Triassic event of the Eastern Fore Caucasus are both related to continental rifting of a previously deformed and peneplaned basement. The rifting was due to tensional lithospheric stresses in the Donbas (Saintot et al 2003), and more likely transtensional in the Eastern Fore Caucasus (Gaetani 2000).

At Late Devonian times, subaerial basaltic lava flows were emplaced at the beginning of the Donbas rift formation (figure 1) (McCann et al 2003 and ref. therein), well after the final Proterozoic consolidation of the Sarmatia basement (at $1500 \mathrm{Ma}$, according to Milanovsky 1996 and references therein, or at 2000-1800 Ma according to Bogdanova et al 1996).

From Early to Late Triassic times, three mafic volcanic suites, including some rhyolitic materials, were emplaced successively in continental and marine sedimentary environments on the Eastern Fore Caucasus (figure 1) (Tikhomirov et al 2004 and ref. therein), some tens of millions years after the basement consolidation of the Scythian Platform if Variscan or some hundreds of millions years after, if Baikalian.

Remark: The time gap between the last orogeny and continental rifting is important to specify in as much as the petrotectonic setting of these continental rifting-related eruptions is usually described as "anorogenic or continental intra-plate", and "postorogenic or post-collisional" after either a long or a short time gap respectively. A priori, this time gap does not allow defining the depth, lithospheric or asthenospheric or even deeper, of mantle partial melting synchronous with the continental rifting process.

Two types of volcano-sedimentary environments developed, expressing the competition between uplift and subsidence at surface. Whereas the Late Devonian and Late Triassic volcanoes were subaerial and associated with intra-continental basins (active rifting with uplift prevailing over subsidence), the Early to Middle Triassic volcanoes emplaced within marine basins upon continental crust (passive rifting with subsidence prevailing over uplift).

In time and at large scale, the Late Devonian and the Triassic periods were both the early stages of a continental crust thinning process leading to the formation of continental marine basins (Nikishin et al 1996; Stovba and Stephenson 1999; Nikishin et al 1998a, b). Nevertheless the geodynamic setting of these basins is still under discussion especially for the Late Devonian time slice.
The Donbas rift belongs to the Prypiat-DnieprDonets (PDD) mega-rift (figure 1). This Late Devonian structure was contemporaneous with (1) widespread peri- and intra-cratonic magmatism elsewhere on the whole Eastern European Platform (about 4 million $\mathrm{km}^{2}$ ) from the Timan-Pechora and East Barents Sea rift systems northwards to the Peri-Caspian Basin eastwards (Stephenson et al 2006), (2) the accretion of an intra-oceanic volcanic arc following the eastward subduction, therefore away from the Eastern European Platform of (or part of) the Paleo-Ural Ocean (Puchkov 1997; Brown et al 1998, 2002; Brown and Spadea 1999), and (3) development of extensional basins on the southern margin of the Scythian Platform (on the Greater Caucasus area, Khain 1975). The back-arc position of such remains uncertain despite the fact that a northward subduction zone of the ProtoTethys Ocean has very often been adopted in plate kinematic models (e.g., Adamia et al 1981; Gamkrelidze 1986; Ziegler 1990; Zonenshain et al 1990; Stampfli et al 2001; Stampfli and Borel 2002; von Raumer et al 2003). The closest Paleozoic subduction zone, if any, could have been far to the south, at $600 \mathrm{~km}$ minimum along the Greater Caucasus, remnants of which are mafic and ultramafic rocks interpreted as an ophiolitic complex Devonian in age (Khain 1975; Adamia et al 1981) and emplaced prior to the late Visean (Khain 1975; Adamia et al 1981). Whereas Zonenshain et al (1990) considered this ophiolitic series as the suture of a wide ocean basin, that is, "proto-Tethys" or a branch of the Iapetus-Tornquist oceanic system, Adamia et al (1981) suggested the closure of a small back-arc oceanic basin with the main subduction zone south of the Transcaucasus area (Adamia et al 1981; Gamkrelidze 1986). However, if a Paleozoic subduction zone existed south of the Eastern European Platform, it seems unlikely to be responsible for the widespread peri- and intra-cratonic magmatism of the immense Eastern European Platform.

The Early Mesozoic subduction of Paleo-Tethys Ocean beneath Eurasia is better constrained. It should have been just north of the Lesser Caucasus and in Turkey along the Pontides (Stampfli et al 2001; Nikishin et al 2001; Dercourt et al 1993 and 2000 and all references therein). Therefore, the Eastern Fore Caucasus area was somewhat far $(600 \mathrm{~km}$ minimum $)$ from the subduction-related margin of the Paleo-Tethys. Furthermore, the Fore Caucasus basin formed probably onto the northern passive margin of a widespread back-arc basin behind this active margin. The Late Triassic volcanic cycle ended along with a general uplift of the Fore Caucasus area which lasted until the end of Jurassic. Then the overlying undisturbed 
marine Cretaceous cover attests to a stable Eastern European Platform, overlapped by the worldwide transgression.

The compositional changes recorded in the lithospheric continental mantle during orogenic events, are mainly due to its interactions with the crust, oceanic and continental, during the subduction processes during the closure of an ocean and the collision between its margins (Doglioni et al 1999). As mafic eruptive rocks are the most important source of information on mantle compositions, we have undertaken a comparative study of mafic volcanics emplaced on the Eastern European Platform margin during two successive continental rifting periods.

The aims of our petrological study of these basaltic (s.l.) rocks, based on petrographic, geochemical and isotopic (Rb-Sr; Sm-Nd) data on whole rocks, are:

- to decipher and compare the compositions of mantle-derived magmas emplaced on a continental lithospheric plate;

- to deduce and compare the compositions of their possible mantle sources;

- to relate these results to the regional geodynamics.

\section{Detailed geological background of both eruptive areas}

\subsection{Donbas Foldbelt and Late Devonian volcanics}

The Donbas Foldbelt forms the inverted part of the $2000 \mathrm{~km}$-long NW-SE-trending intracratonic Late Paleozoic Pripyat-Dniepr-Donets rift which developed on the south-western part of the Eastern European Platform (figure 1) (Chekunov et al 1992; Stephenson et al 1993). The rift cuts across the roughly $\mathrm{N}-\mathrm{S}$ main structural grain of the Precambrian basement, and has separated the latter in two massifs, the Ukrainian Shield to the north and the Voronezh Massif to the south (figure 1). The Donbas Foldbelt consists of a folded Middle Devonian to Upper Carboniferous volcanosedimentary sequence up to $22 \mathrm{~km}$ thick (Chekunov et al 1993; Stovba et al 1996). The tectonic inversion of the Donbas is Mesozoic (Latest Triassic and Latest Cretaceous) and not Permian (Stovba and Stephenson 1999; Saintot et al 2003) as classically described and presented as such in figure 1. The Permian tectonics of the Donbas is tensional leading to a rift reactivation associated with salt diapirism (Stovba and Stephenson 1999, 2003).

At the onset of lithospheric extension in Middle Devonian time, the Proterozoic Priazov and
Voronezh Massifs, to the west of the Donbas area, underwent passive rifting with a shallow marine sedimentation (Nikishin et al 1996; Alekseev et al 1996). During the Late Devonian, continental rifting associated with basement uplift, fluviatile sedimentation and subaerial basaltic volcanism occurred from the Pripyat-Dniepr-Donets system in the south to the Barents Sea in the north (Chirvinskaya and Sollogub 1980; Wilson and Lyashkevich 1996; Stovba and Stephenson 1999; McCann et al 2003).

Our sampling area of basalts is located on the southern margin of the Donbas Foldbelt $(30 \mathrm{~km}$ to the south of the city of Donetsk) (figure 1). The geology of the region is characterised by a series of WNW-trending half grabens filled with Middle Devonian to lower Visean volcano-sedimentary deposits. The earliest eruptions are Late Devonian basaltic fissure eruptions. The basalts are interstratified with fluviatile deposits. According to McCann et al (2003), uplift and fault activity predated and went on during eruptions. The studied samples come from lava flows (Df in table 1) and their possible feeder dykes (Dd in table 1) cross-cutting the Proterozoic basement to the south.

\subsection{Eastern Fore-Caucasus area and Triassic volcanics}

The Eastern Fore Caucasus is located in the eastern part of the Scythian Platform, between the East European Craton and the Great Caucasus Alpine belt (figure 1), few hundred kilometers from the Donbas area. As previously mentioned, the nature of the Scythian Platform basement is unknown and few are available on the Paleozoic succession.

The accessible data come from few boreholes reaching the Permo?-Triassic rocks between 3 and $6 \mathrm{~km}$. These deposits have a highly variable thickness (up to $2 \mathrm{~km}$ ). They unconformably overlie the older Paleozoic succession and are covered by Jurassic (Pliensbachian and younger) strata. The Paleozoic (Devonian to latest Carboniferous) succession shows greenschist facies metamorphism, and is intruded by Carboniferous to Early Permian granites (Letavin 1980).

According to the classical scheme of evolution (Zonenshain et al 1990; Nikishin et al 2001), after the Late Paleozoic folding and granitic intrusions, the Fore-Caucasus area was uplifted during Late Permian and eroded while continental sedimentation occurred eastwards.

Another interpretation could be as follows: the greenschist metamorphism was the result of a deep burial of the Devonian to latest Carboniferous succession before its exhumation and erosion 
during the widespread Permian uplift of the southern Eastern European Platform. This uplift was synchronous with a widespread continental rifting affecting not only the southern margin of the Eastern European Platform, but also the western Variscan Europe as well as the northern Europe (Ziegler 1990). No Late Paleozoic penetrative deformation is recorded in the succession of the Scythian Platform (Stephenson et al 2004; Saintot et al 2006). Where high grade metamorphism of the Scythian Platform basement is observed, as in the Stavropol High region, it is reported to be Baikalian in age (Belov 1981). As the basement of the Pre-Caspian basin, lying north of the area of interest, could contain relics of eclogites, Baikalian in age (Volozh 2003), the last major orogenic event recorded by the Scythian Platform could likely be Baikalian rather than Variscan.

During Triassic times, periods of continental and marine sedimentation alternated with some hiatuses in-between. The total rate of subsidence varied, being very low or even null in the central part (the Stavropol High) relative to the western and eastern parts.

Three eruptive cycles, in Early (T1), Middle (T2) and Late (T3) Triassic times, are recognized (Tikhomirov et al 2004 and references therein). They correspond to two different sedimentation epochs [Early to Middle Triassic $=\mathrm{T} 1-\mathrm{T} 2$ ] and $[$ Late Triassic $=\mathrm{T} 3]$ separated by a period of strong uplift and erosion. T1, T2 and T3 eruptive cycles followed each other in time over about $50 \mathrm{Ma}$.

The Early (T1) and Middle (T2) Triassic sequences include both transgressive (Early Triassic) and regressive (Middle Triassic) series. Continental clastics at the foot of Triassic strata presumably fill linear NW-SE striking troughs. In time, the sedimentation area widened, and continental clastic sedimentation was gradually replaced by marine clastic and carbonate accumulation. The maximal transgression corresponds to the Olenekian times when the Scythian platform was almost completely immersed. A marine carbonate sedimentation with bioherms dominated in the shallow central part of the Kayasula basin, while two deeper basins of terrigeneous sedimentation developed both to the north (Karpinsky) and to the south.

Eruptions of basaltic submarine lava flows associated with some rhyolitic and dacitic flows and domes occurred during both Early (T1) and Middle (T2) Triassic periods at the northern limit of the Kayasula area on the East Manych narrow zone (Nikishin et al 2001). They are interstratified with significant volumes of clastic marine sediments.
This volcano-sedimentary sequence is unconformably overlain by $300 \mathrm{~m}$ thick Ladinian (late Middle Triassic) subaerial (?) clastic rocks, reworking products of the volcanics.

Throughout this Early to Middle Triassic period, the tilting of strata at small and large scales attests for a high degree of instability of the basement. During the Early Triassic (T1), another eruptive zone located southwards to the East Manych zone would have been the source of rhyolitic ash falls.

Thus, T1 and T2 eruptions respectively occurred during the opening (increase of the subsidence rate during a passive syn-rifting process), then the disappearance (decrease of the subsidence rate during a passive post-rifting process) of a marine basin. That suggests a change/release of the lithospheric stresses.

In Late Triassic times (T3), the entire ForeCaucasus area was first uplifted, tilted and deeply eroded during the Carnian. Then during the Norian, a huge event of subaerial eruptions occurred synchronously with a fluvio-lacustrine sedimentation (Tikhomirov et al 2004 and ref. therein). This T3 volcano-sedimentary sequence, named the Nogai Formation (Dubinskii and Matsenko 1965), is up to $1500 \mathrm{~m}$ thick. A few mafic lava flows (T3 in table 1) are interstratified with enormous volumes of rhyolitic and dacitic ignimbrites and related fall deposits. The sediments accumulated within a NW-SE striking linear depression superposed on the East Manych zone, suggesting an intra-continental rifting environment. The Nogai Formation was partially overlain by the Rhaetian Zurmutinskaya continental suite (up to $300 \mathrm{~m}$ thick) including minor rhyolitic tuffs. The same environment, but without volcanism, prevailed during Jurassic times.

\section{Petrography of the basaltic rocks}

\subsection{Late Devonian group}

The Late Devonian (D) basaltic samples, either from lava flows or dykes, are microlitic (25 to $50 \%$ ), mostly porphyritic (1 to $8 \mathrm{~mm}$ in diameter; 1 to $20 \%$ in volume), and frequently microvesiculated. Minerals are Ti-augite (with frequent sector-zoning and concentric zoning), and/or pseudomorphs of olivine (not as microlites), and/or plagioclase (often as microlites only), magnetite, apatite (abundant in UK16) and sometimes brown hornblende. Mantle xenocrysts (deformed and partially resorbed olivine and pyroxene) are sometimes observed (UK44A1). More detailed descriptions are in McCann et al (2003). 


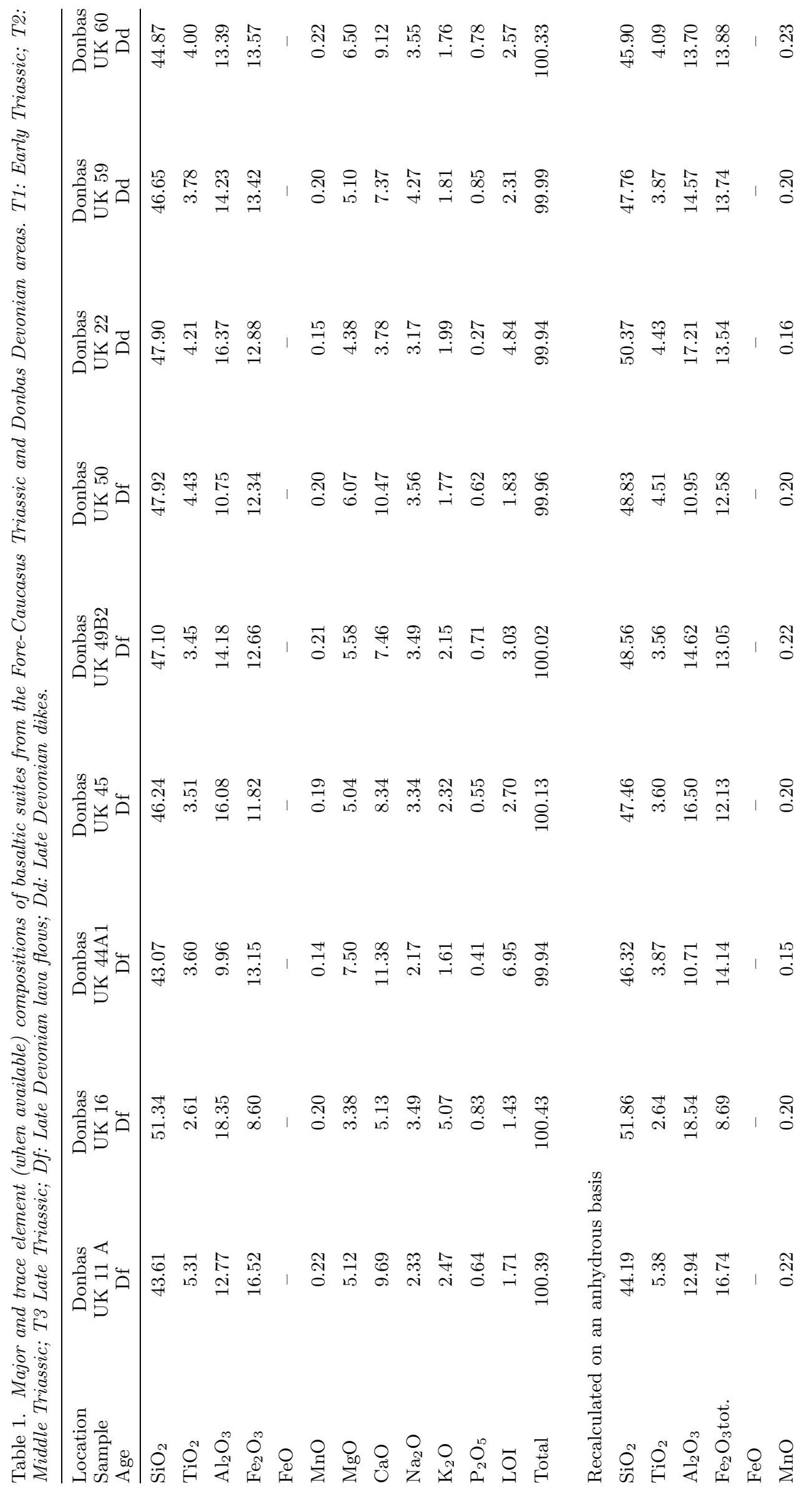


兽

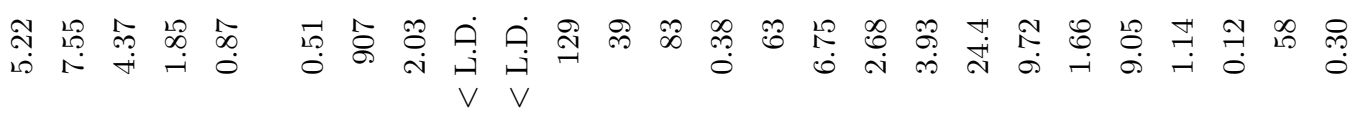

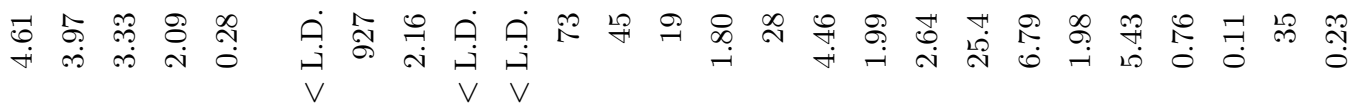

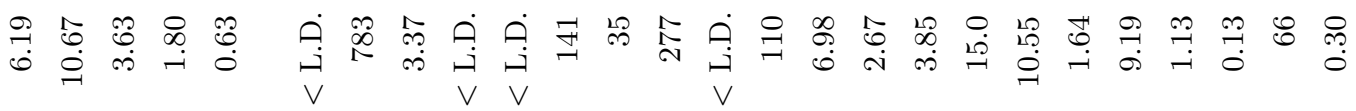
扂

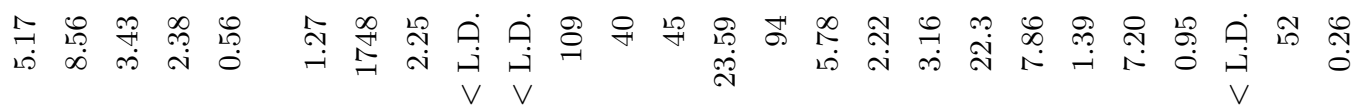

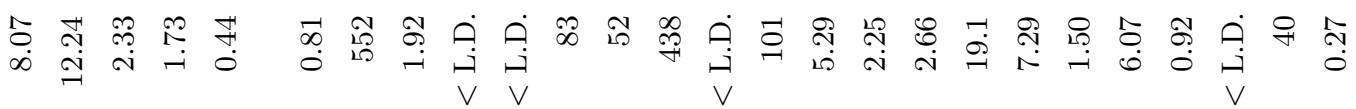

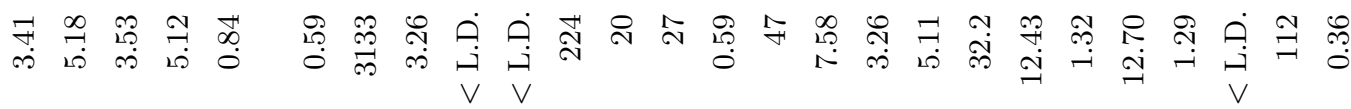

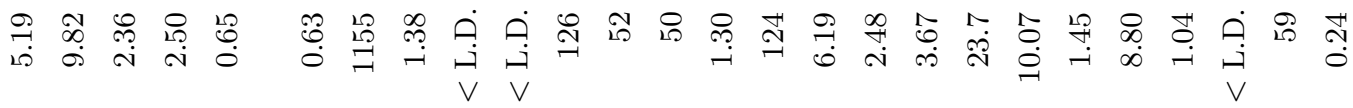

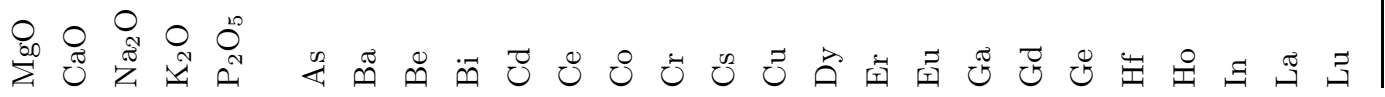




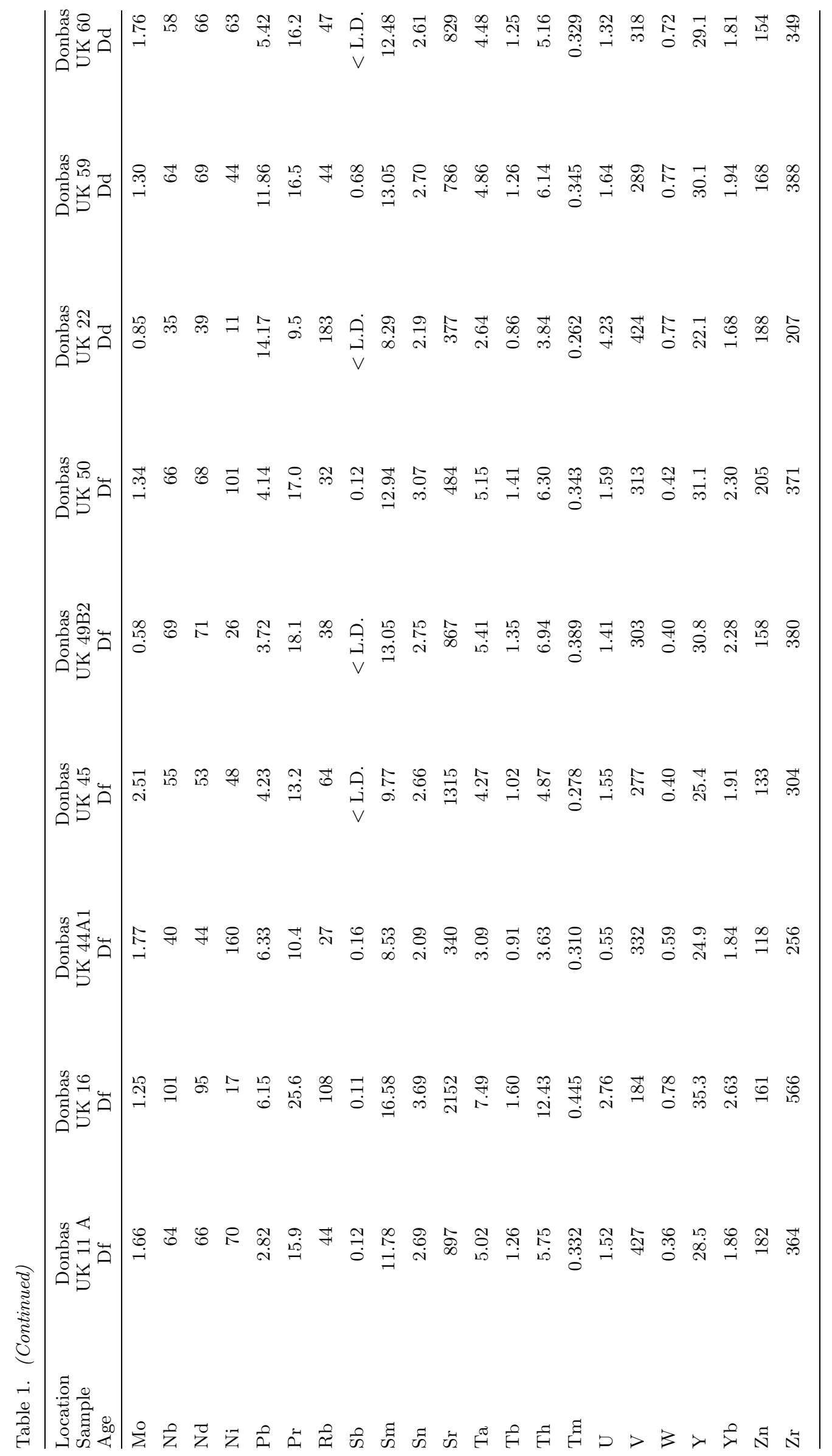




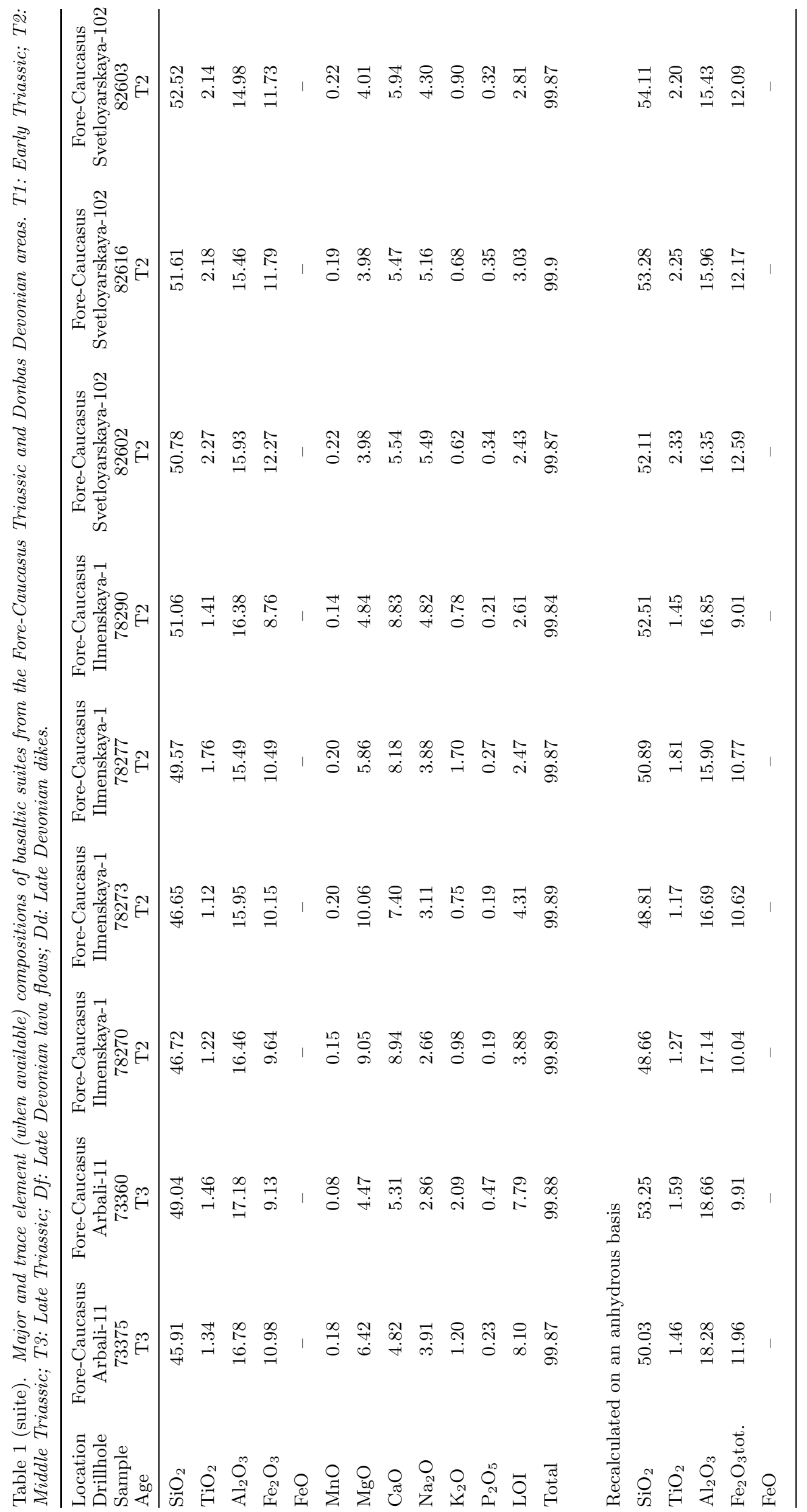




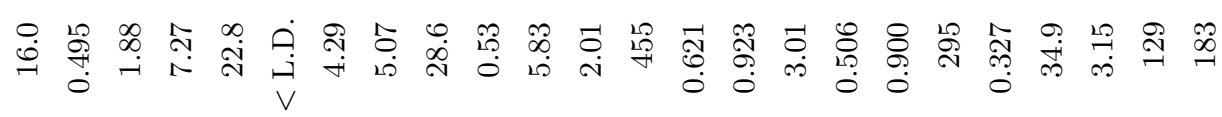

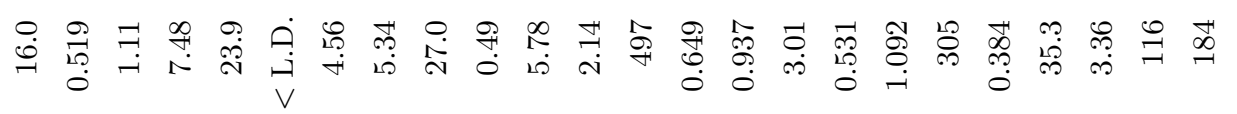

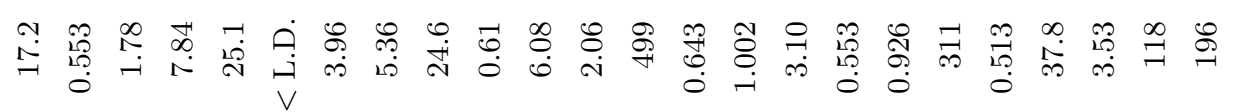

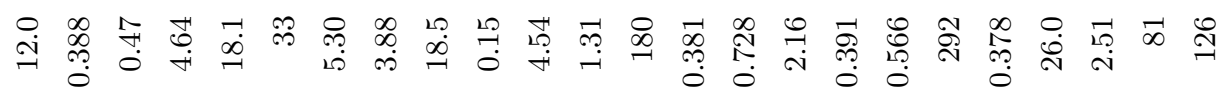

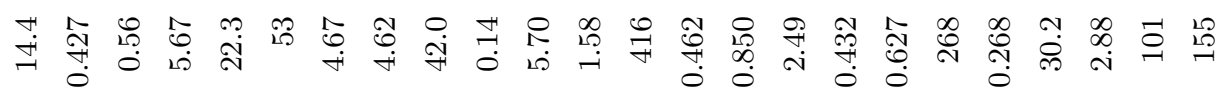

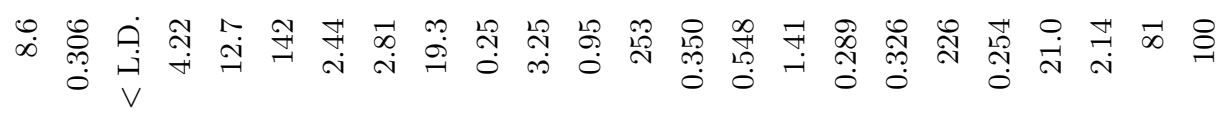

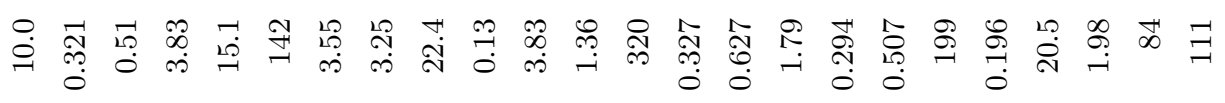

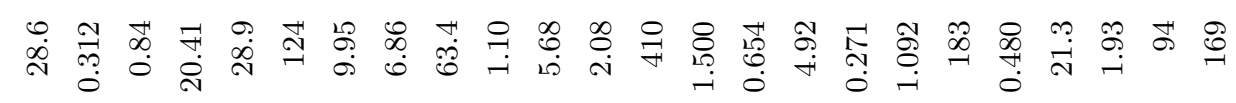

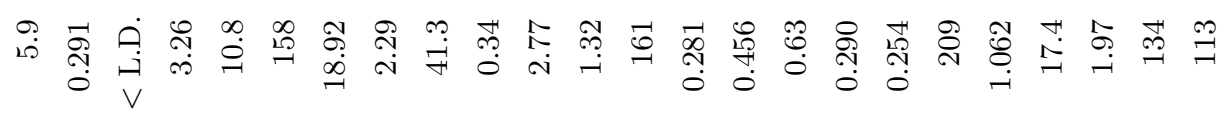

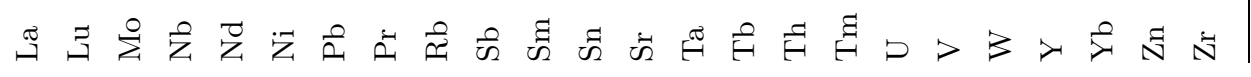




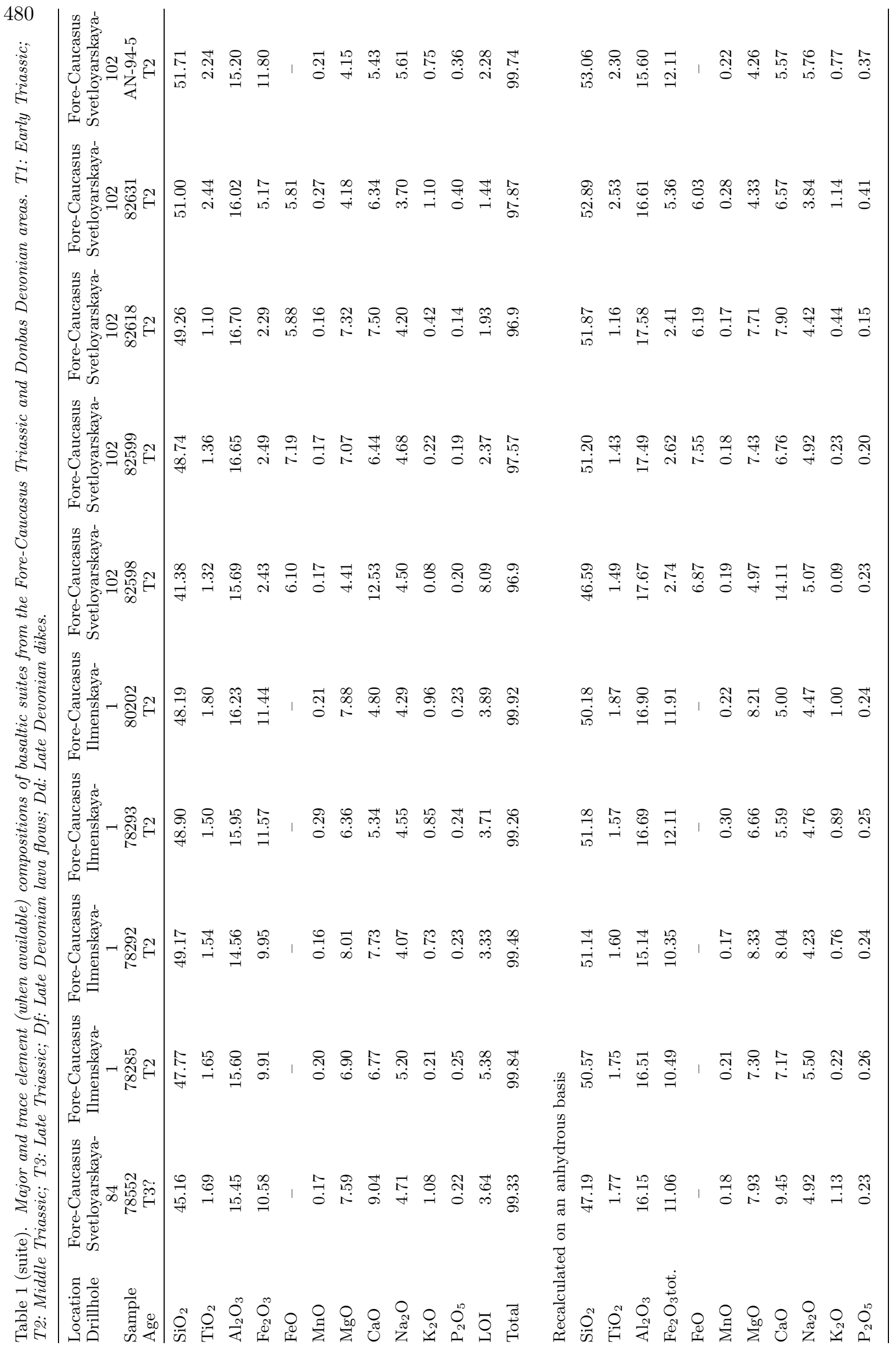




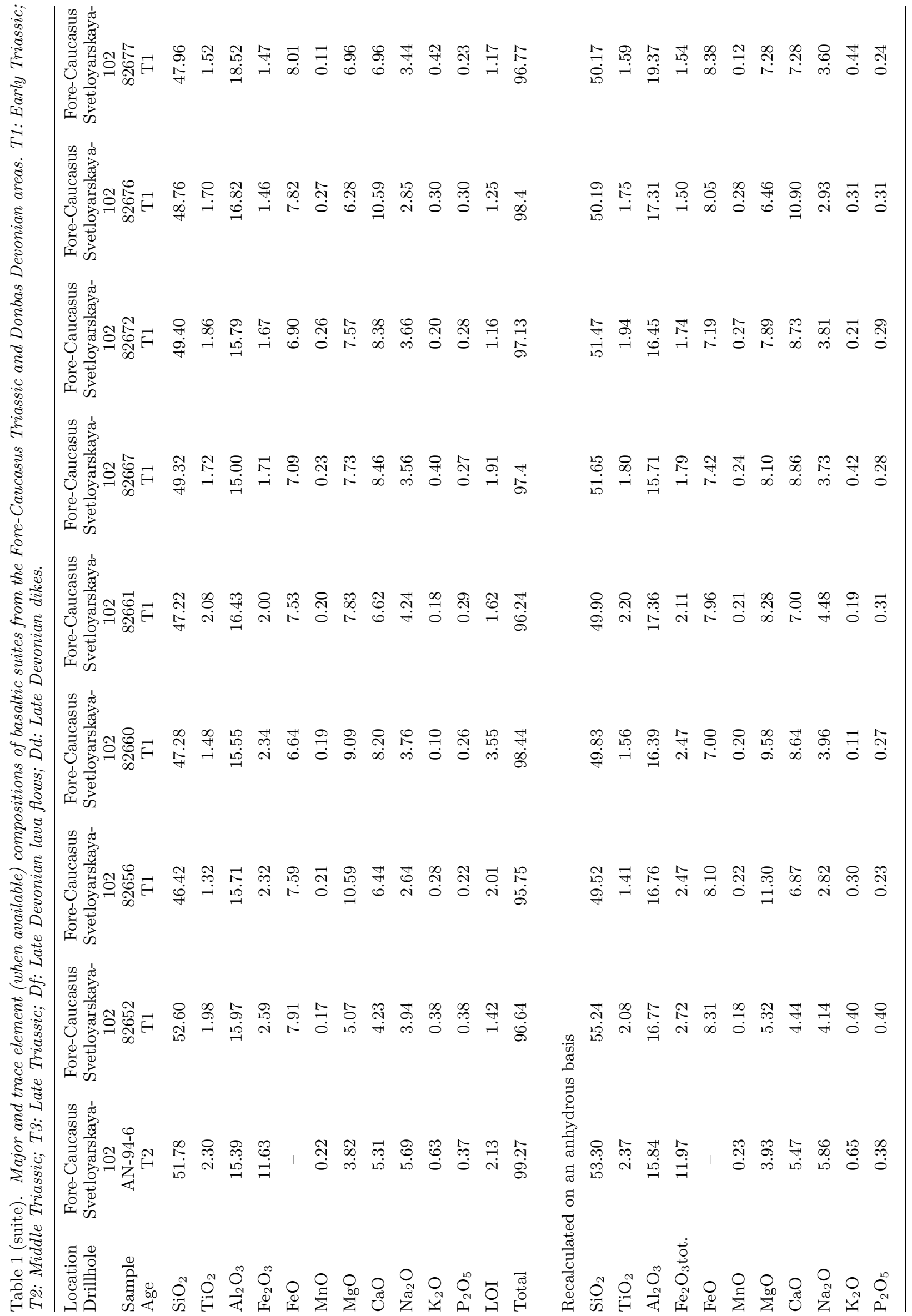




\subsection{Triassic groups}

The Early (T1) and Middle (T2) Triassic basic rocks do not differ from each other. They comprise basalts, dolerites, and gabbros forming a series of lava flows and cognate subsurface intrusions. Basalts and basaltic andesites are sparsely porphyritic (1 to $3 \%$ of olivine and rare plagioclase, $1-3 \mathrm{~mm}$ in size), massive or vesicular (up to $10 \%$ by volume). Groundmass often has a quenched texture with hollow 'box-shaped' plagioclase and skeletal pyroxene, typical of subaqueous basic lavas. Dolerites and gabbros are massive, mainly poikilitic or equigranular, with large (up to $5 \mathrm{~mm}$ ) brown augite (40-50\%) including numerous weakly zoned plagioclase $\mathrm{An}_{40-60}(55-45 \%)$, ilmenite and Ti-magnetite (up to 5\%).

The Late (T3) Triassic basic rocks are found as lava flows and subsurface intrusions. Basalts are somewhat more crystal rich than $\mathrm{T} 1$ and T2. The phenocrysts (up to $10-15 \%$ by volume; $1-5 \mathrm{~mm}$ in size) include plagioclase, corroded olivine, augite and sometimes brown amphibole, scattered within an intersertal matrix. Dolerites are usually equigranular, never poikilitic, with the same mineralogical assemblage than $\mathrm{T} 1$ and $\mathrm{T} 2$. More detailed descriptions are in Tikhomirov et al (2004).

In summary, there are no significant petrographic differences between these groups of alkaline basic rocks, except that the augite is much more titaniferous in the Late Devonian group, and a brown amphibole appears in the Late Triassic (T3) group. The most massive and less altered samples were chosen for the geochemical study.

\section{Chemical and isotopic compositions of basaltic rocks}

\subsection{Analytical methods}

Both major and trace elements have been analysed respectively by ICP-AES and ICP-MS (SARM; CRPG-CNRS Nancy) on available samples of the Late Devonian and Triassic volcanics. Among the Triassic samples, if major elements are available for mafic rocks of each period, no one Early Triassic (T1) sample was available for trace element and isotopic analysis at CRPG. Besides major element data alone are given for samples analysed by wet chemistry in 1983-84 at the chemical lab of "Ukrchermetgeologia" state enterprise (Khar'kov, Ukraine) and in 1996 at the Leeds University analytical lab (Great Britain). Sr and $\mathrm{Nd}$ isotope data were obtained after standard chemical separation techniques on a Finnigan MAT 262 (CNRS-CRPG; Nancy). Rb and Sm concentration isotope data were determined by isotopic dilution on the ICP-MS Elan 6000.

\subsection{Major element compositions and} preliminary interpretations about mantle source compositions and genetic relationships between volcanics of each group

Major element data from Donbas and ForeCaucasus samples are listed in table 1 . On the whole diagrams, Late Devonian (D), Early (T1), Middle (T2) and Late (T3) Triassic groups are identified. Each of them is successively characterized then compared to each other.

The Late Devonian (D) samples, either lava flows (Df) or feeder dykes (Dd) include, after Le Maitre classification (1989), mainly trachybasalts and rare basanites, basalts and basaltic trachyandesites (figure 2 - data recalculated on an anhydrous basis). The LOI (lost on ignition) values for whole rocks (1.5 to $3 \%$ on average; up to $7 \%$ ) are not related to significant loss or gain in $\mathrm{SiO}_{2}, \mathrm{~K}_{2} \mathrm{O}$ and $\mathrm{Na}_{2} \mathrm{O}$ (figure 3 - untreated data). Nevertheless only data recalculated on an anhydrous basis are plotted in the binary diagrams where $\mathrm{MgO}$ in abscissa is considered as the best discriminator (figure 4). First, no distinction exists between flows and dykes. On the whole, volcanics are rather silica-poor (44 to $49 \%$ in average; up to $52 \%$ ) and alkali-rich (4 to $6 \%$; up to $8 \%$ ) with a moderate $\mathrm{MgO}$ content (8 to $5.5 \%$; down to $3.5 \%$ ) and a $\mathrm{CaO}$ content between 12 and 4\%. They belong to the group of alkali basalts (s.l.). Like alkali basalts,

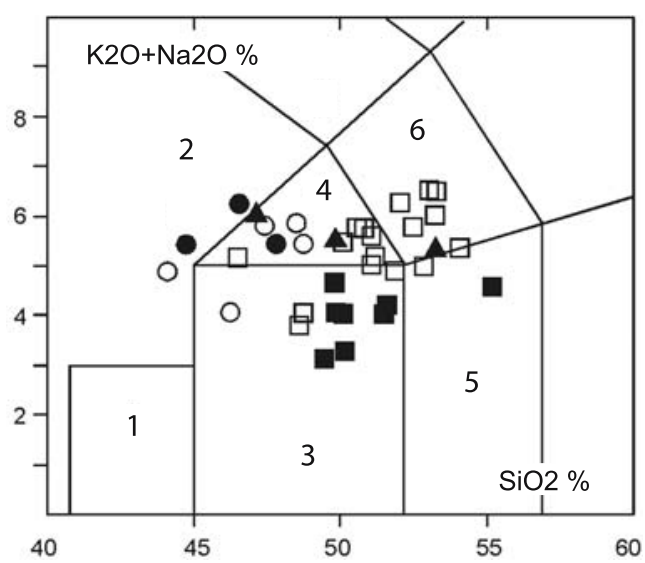

Figure 2. Variations of total Alkali vs. $\mathrm{SiO}_{2}$ (data recalculated on an anhydrous basis) and classification of magmatic whole rocks after Le Maitre (1989). Circle: Late Devonian (D) Donbas volcanics; white: as lava-flow; black: as dyke; square and triangle: Triassic Fore Caucasus volcanics; black square: Early Triassic (T1) lavas; white square: Middle Triassic (T2) lavas; black triangle: Late Triassic (T3) lavas. 1. Picrobasalt; 2. tephrite-basanite; 3 . basalt; 4 . trachybasalt, 5 . basaltic andesite; and 6 . basaltic trachyandesite. 

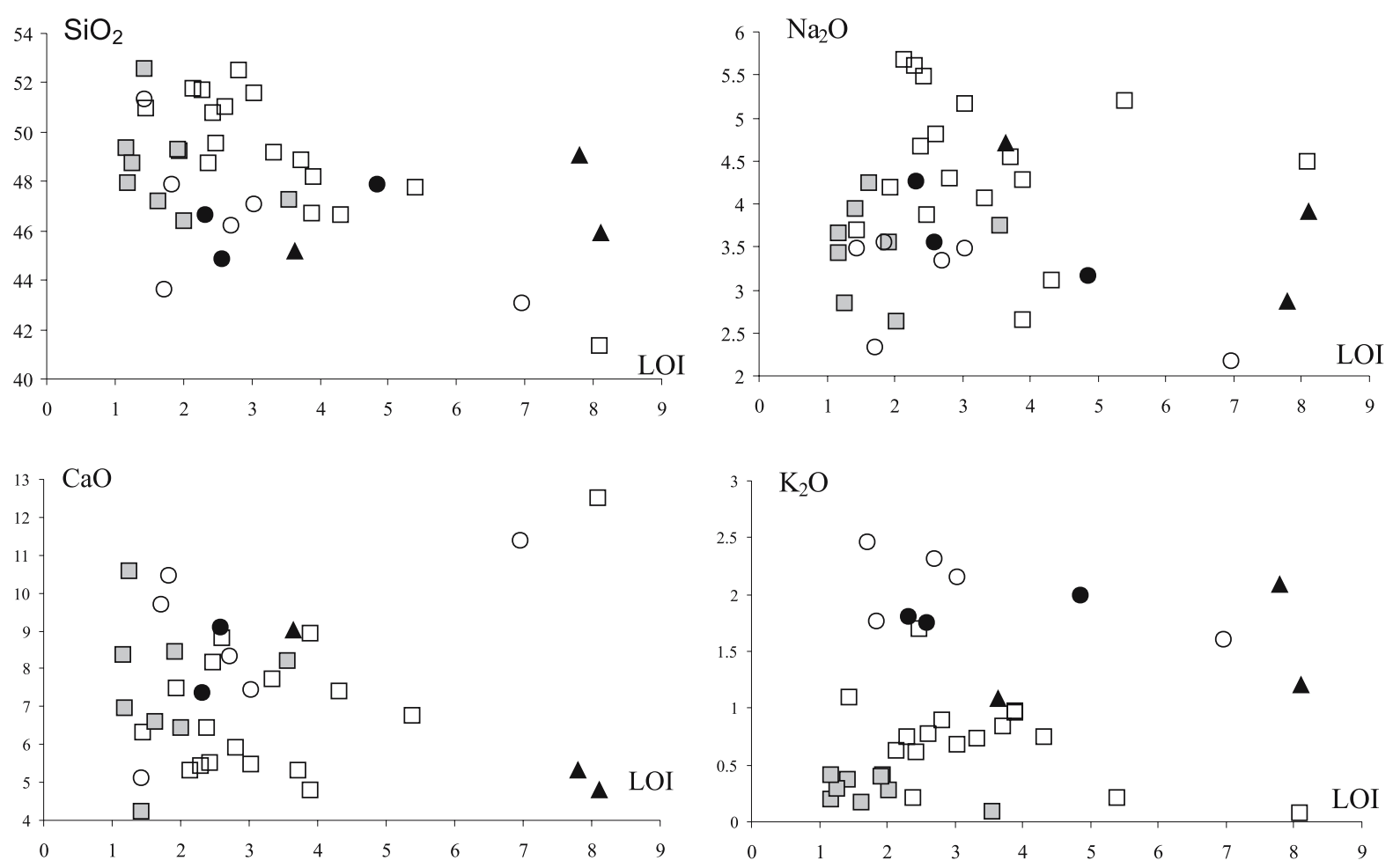

Figure 3. Variations of $\mathrm{SiO}_{2}, \mathrm{Na}_{2} \mathrm{O}, \mathrm{CaO}$ and $\mathrm{K}_{2} \mathrm{O}$ with Loss On Ignition (LOI) on whole-rocks (untreated data). Same symbols as in figure 2 .

they are significantly rich in $\mathrm{TiO}_{2}$ (3.5 to $4.5 \%$ in average; up to $5.4 \%$ ), $\mathrm{FeO}$ (11 to $15 \%$ in average), $\mathrm{P}_{2} \mathrm{O}_{5}$ (0.5 to $1 \%$ ), and rather poor in $\mathrm{Al}_{2} \mathrm{O}_{3}$ (10 to 15\%). Positive correlations exist between $\mathrm{MgO}, \mathrm{FeO}, \mathrm{CaO}$, and $\mathrm{TiO}_{2}$ on one hand, and $\mathrm{SiO}_{2}$, $\mathrm{Al}_{2} \mathrm{O}_{3}, \mathrm{P}_{2} \mathrm{O}_{5}, \mathrm{Na}_{2} \mathrm{O}$ and $\mathrm{K}_{2} \mathrm{O}$ on the other.

Data for the Early (T1) and Middle (T2) Triassic samples do not overlap in the classification diagram (figure 2 - data recalculated on an anhydrous basis), T2 having a higher alkali/silica ratio. $\mathrm{T} 1$ includes basalts and rare andesites, whereas T2 comprises basalts, trachy-basalts and trachyandesitic basalts and rare basaltic andesites. Both groups show a positive correlation between alkali and silica. The LOI (lost on ignition) contents of T1 samples (figure 3 - untreated data) are rather low (up to $2 \%$ ) and do not show any correlation with silica, alkali and $\mathrm{CaO}$. In turn, the somewhat higher LOI contents (up to 4\%) of T2 samples are correlated with more or less significant loss in $\mathrm{SiO}_{2}$ and $\mathrm{Na}_{2} \mathrm{O}$. As for the Donbas samples, only data recalculated on an anhydrous basis are plotted against $\mathrm{MgO}$ in the binary diagrams (figure 4). $\mathrm{T} 1$ and $\mathrm{T} 2$ data overlap in most diagrams, except that $\mathrm{T} 2$ rocks have slightly lower $\mathrm{P}_{2} \mathrm{O}_{5}$ and higher $\mathrm{K}_{2} \mathrm{O}$ contents than T1 rocks. These differences could be primary in as much as it is a feature of the whole group and there is no correlation between both oxides and LOI variations. Besides some T1 and T2 samples contain more than $10 \%$ $\mathrm{MgO}$, and are relatively primitive rocks. On the whole, $\mathrm{SiO}_{2}, \mathrm{TiO}_{2}, \mathrm{Na}_{2} \mathrm{O}$ and $\mathrm{P}_{2} \mathrm{O}_{5}$ are inversely correlated with $\mathrm{MgO}$, whereas $\mathrm{K}_{2} \mathrm{O}, \mathrm{CaO}, \mathrm{FeO}$ and $\mathrm{Al}_{2} \mathrm{O}_{3}$ do not show significant variations with $\mathrm{MgO}$ decrease.

The Late Triassic T3 samples are mostly trachybasalts (figure 2), slightly more potassic than T1 and T2 (figure 4). The small number of available samples does not allow evaluation of positive correlation of their rather high LOI contents with $\mathrm{K}_{2} \mathrm{O}$ and $\mathrm{SiO}_{2}$ and negative correlation with $\mathrm{Na}_{2} \mathrm{O}$ and $\mathrm{CaO}$ (figure 3 - untreated data). In figure 4 , the T3 compositional field overlaps more or less with the T2 and T1 ones. Nevertheless T3 shows significant and sometimes opposite variations between major elements compared to those existing within $\mathrm{T} 1$ and $\mathrm{T} 2$. In T3, $\mathrm{SiO}_{2}, \mathrm{~K}_{2} \mathrm{O}$ and $\mathrm{Al}_{2} \mathrm{O}_{3}$ are negatively correlated with $\mathrm{MgO}$, whereas $\mathrm{CaO}, \mathrm{FeO}$ and $\mathrm{TiO}_{2}$ are positively correlated with $\mathrm{MgO}$. Note that $\mathrm{T} 3$ shows a positive correlation between $\mathrm{MgO}$ and $\mathrm{Na}_{2} \mathrm{O}$ and the strongest opposite correlation between $\mathrm{Na}_{2} \mathrm{O}$ and $\mathrm{K}_{2} \mathrm{O}$. Nevertheless both features could be due to some loss in $\mathrm{Na}_{2} \mathrm{O}$ with alteration.

Preliminary interpretations: The Late Devonian (D) and Triassic (T) basic rocks are both rather alkali-rich with a more or less high alkali/silica ratio, an indication of mantle sources of rather 

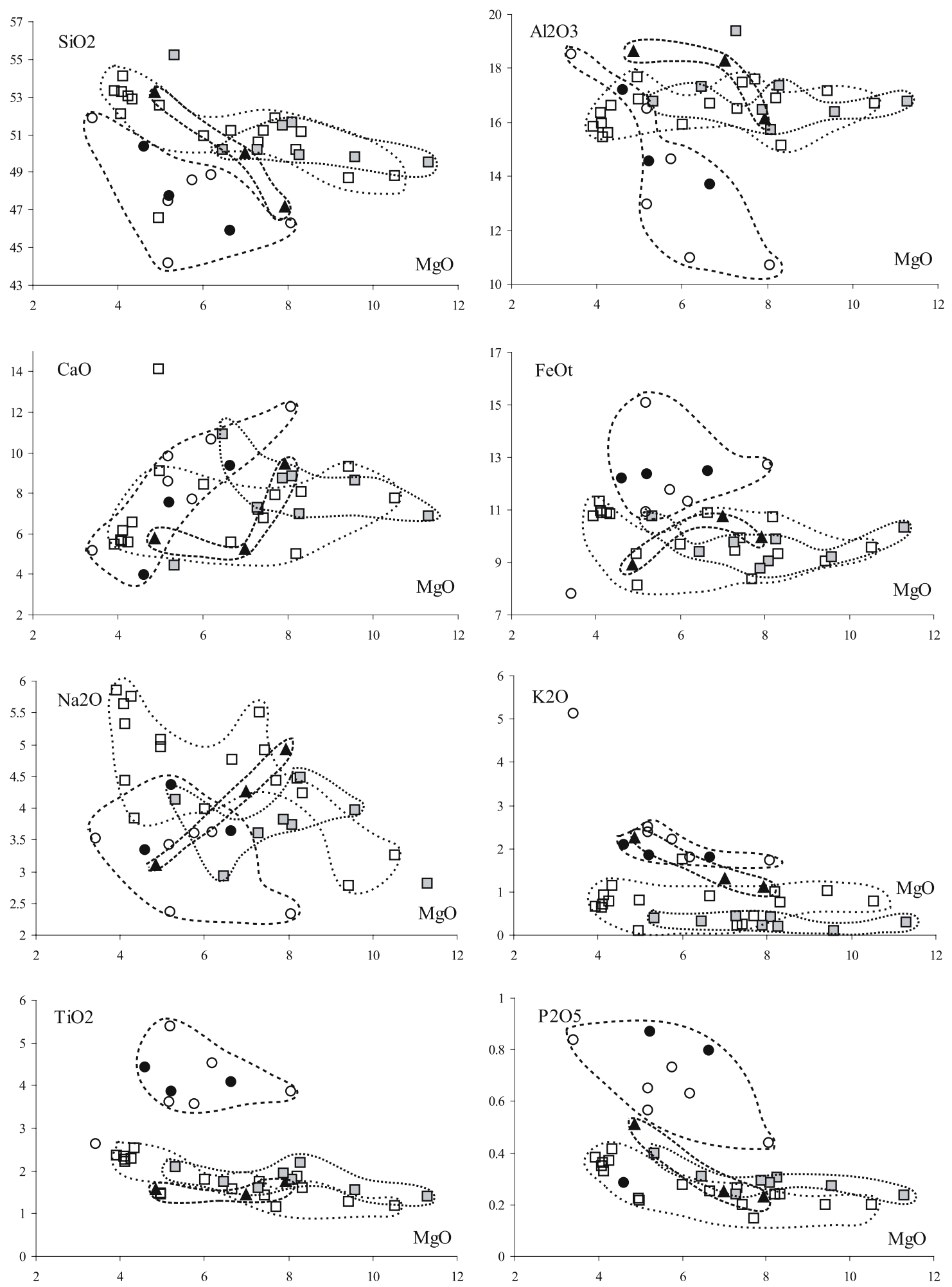

Figure 4. Variations of major oxides vs. $\mathrm{MgO}$ (data recalculated on an anhydrous basis). Same symbols as in figure 2 . The scatter in the data for each group is evidenced.

similar compositions. Nevertheless each group has its own specificity. The D samples display the whole features of alkaline and titaniferous mafic series (after Wilson 1989), whereas the T samples display the characteristics of rather Kpoor and calc-alkaline silica-saturated series (after Wilson 1989), somewhat poorer in $\mathrm{TiO}_{2}$ and total alkali, but richer in $\mathrm{SiO}_{2}$ than the $\mathrm{D}$ group. 

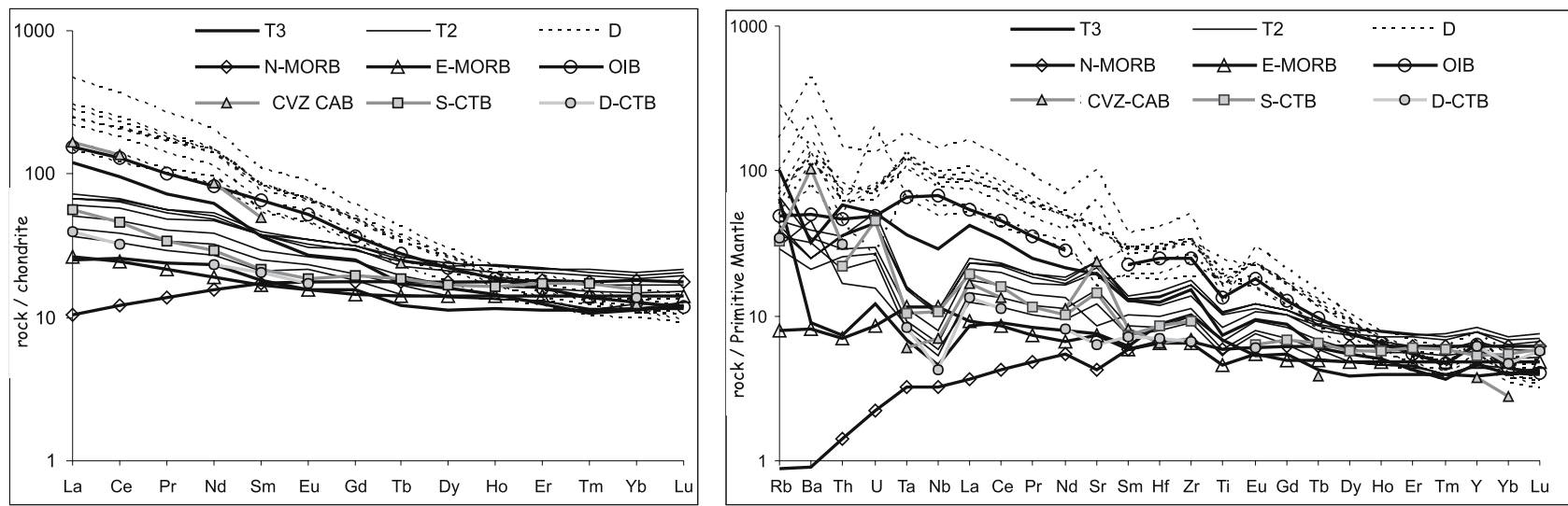

Figure 5. Chondrite-normalized Rare Earth Element spidergrams and Primitive Mantle-normalized Trace Element spidergrams for Late Devonian (D), Middle (T2) and Late (T3) Triassic samples. The spidergrams of N-MORB, E-MORB and OIB (ref. http://earthref.org/GERM/reservoirs), a calc-alkaline basalt from the Central Volcanic Zone of the Andes (CVZCAB) (in Wilson 1989) and continental tholeiitic basalts from Siberia (S-CTB) and Deccan (D-CTB) traps (in Lightfoot et al 1990a and b) are shown for comparison.

These specificities suggest compositional variations in both proportions and compositions of alkali- and titanium mantle minerals (metasomatic hydrated phases as amphibole and/or phlogopite) from one source to another. In that case, the sources were all within volatile-enriched mantle zones.

Besides, T1 and T2, and T3 and D appear to differ in their evolutionary trends. Correlations between $\mathrm{MgO}$ and $\left[\mathrm{CaO}, \mathrm{FeO}, \mathrm{TiO}_{2}\right]$, negative or insignificant in $\mathrm{T} 1$ and $\mathrm{T} 2$, are positive in $\mathrm{T} 3$ and $\mathrm{D}$; whereas the correlations between $\mathrm{MgO}$ and $\left[\mathrm{SiO}_{2}, \mathrm{Al}_{2} \mathrm{O}_{3}, \mathrm{~K}_{2} \mathrm{O}\right]$, somewhat insignificant in $\mathrm{T} 1$ and $\mathrm{T} 2$, are negative in $\mathrm{T} 3$ and $\mathrm{D} . \mathrm{P}_{2} \mathrm{O}_{5}$ always displays a negative correlation with $\mathrm{MgO}$, significantly higher in D and T3 than in T1 and T2. According to petrographical observations, as no evidence of magma mixing is observed, these variations should originate from fractional crystallization processes.

\subsection{Trace element compositions and preliminary interpretations about mantle source compositions and genetic relationships between volcanics of each group}

Trace element data of Donbas (Late DevonianD) and Fore-Caucasus (Middle-T2 and Late-T3 Triassic) samples are listed in table 1. Trace element data for Early Triassic (T1) volcanics do not exist as the samples were no more available. On Chondrite (CH)-normalized Rare Earth Element and Primitive Mantle (PM)normalized trace element spidergrams (figure 5), incompatibility of elements during partial melting of mantle increases towards the left. For comparison, spidergrams of Normal Mid-Oceanic
Ridge Basalts (N-MORB) (Salters and Stracke 2004), Enriched Mid-Oceanic Ridge Basalts (E-MORB) and Oceanic Island Basalts (OIB) (ref. http://earthref.org/GERM/reservoirs), of a calcalkaline basalt from the Central Volcanic Zone of the Andes (CVZ-CAB) (in Wilson 1989) and of continental tholeiitic basalts from Siberia (S-CTB) and Deccan (D-CTB) traps (in Lightfoot et al 1990a and b) are plotted in figure 5 .

The trace element composition of each magmatic group is studied in order to decipher the composition of its mantle source on one hand and on another hand the genetic relationships (partial melting and/or fractional crystallization) existing among samples of any group. Our approach is as follows. First, their main compositional features (\# magmatic affinity) are evidenced by the trace element total contents, the PM-normalized ratios between elements either among the most incompatible or with close incompatibility during mantle partial melting $\left[\mathrm{Th}_{\mathrm{n}} / \mathrm{Ta}_{\mathrm{n}}, \mathrm{Th}_{\mathrm{n}} / \mathrm{La}_{\mathrm{n}}, \mathrm{La}_{\mathrm{n}} / \mathrm{Sm}_{\mathrm{n}}\right.$, $\left.\mathrm{Nb}_{\mathrm{n}} / \mathrm{Zr}_{\mathrm{n}}, \mathrm{Sm}_{\mathrm{n}} / \mathrm{Zr}_{\mathrm{n}}\right]$ and between the most and the less incompatible $\left[\mathrm{Th}_{\mathrm{n}} / \mathrm{Yb}_{\mathrm{n}}, \mathrm{Ta}_{\mathrm{n}} / \mathrm{Yb}_{\mathrm{n}}, \mathrm{La}_{\mathrm{n}} / \mathrm{Yb}_{\mathrm{n}}\right]$. These ratios, preserved on the whole during magmatic differentiation, are tracers of not only the mantle source composition but also the partial melting degree which can increase if it is low, or decrease if it is high, the primary compositional features of the mantle. Then partial melting and fractional crystallization trends are evidenced in correlating between them contents, or ratios, between some trace and major elements which have contrasted behaviors from one process to another, i.e.,

(1) $\left[\mathrm{Th}_{\mathrm{n}}, \mathrm{Ta}_{\mathrm{n}}, \mathrm{La}_{\mathrm{n}}, \mathrm{SiO}_{2}\right]$ which decrease but not at the same rate with mantle melting increase, 
and which increase at the same rate during basic magma crystallization;

(2) $[\mathrm{Ni}, \mathrm{Cr}]$ and $[\mathrm{MgO}]$ which respectively barely or strongly increase with mantle melting increase;

(3) $\left[\mathrm{Th}_{\mathrm{n}} / \mathrm{Ta}_{\mathrm{n}}, \mathrm{La}_{\mathrm{n}} / \mathrm{Ta}_{\mathrm{n}}\right]$ which slightly decrease with mantle melting increase, and remain constant or slightly increase during crystallization of a basic magma.

\subsubsection{Late Devonian (D) group}

No difference exists between feeder dyke and flow samples. On CH-normalized rare earth element spidergrams (figure 5), the patterns are similar, parallel, generally more enriched than OIB with similar to much higher $\mathrm{La}_{\mathrm{n}} / \mathrm{Yb}_{\mathrm{n}}$ (mostly 15 to 23 ; up to 30). The same is observed on PM-normalized trace element spidergrams (figure 5), except that some samples can show more or less accentuated unusual anomalies, positive in $\mathrm{Ba}$ and $\mathrm{Sr}$, negative in $\mathrm{U}$ and Ti. The PM-normalized total trace element content in each sample is rather high (sumTE: $1200 \mathrm{ppm}$ in average; figure 6$)$. The ratios $\mathrm{Th}_{\mathrm{n}} / \mathrm{Ta}_{\mathrm{n}}(0.55$ to 1$), \mathrm{Th}_{\mathrm{n}} / \mathrm{La}_{\mathrm{n}}(0.7$ to 0.9 ; up to 1.3$), \mathrm{La}_{\mathrm{n}} / \mathrm{Sm}_{\mathrm{n}}$ (3 to 3.6; up 4.3), $\mathrm{Sm}_{\mathrm{n}} / \mathrm{Zr}_{\mathrm{n}}$ (0.7 to 1) are rather steady within the group. None $\mathrm{Ta}$ and $\mathrm{Nb}$ negative anomalies exist. The ratios $\mathrm{Th}_{\mathrm{n}} / \mathrm{Yb}_{\mathrm{n}}$ (10 to 20), $\mathrm{Ta}_{\mathrm{n}} / \mathrm{Yb}_{\mathrm{n}}$ (10 to 30 ) and $\mathrm{La}_{\mathrm{n}} / \mathrm{Yb}_{\mathrm{n}}$ (15 to 25 ), even if they vary within the group, remain higher than in all the other groups. Such patterns are typically those of alkaline and titaniferous basic volcanics as already defined with major elements (after Wilson 1989).

Preliminary interpretations: The features of the Late Devonian (D) volcanics could be interpreted in two ways:

(1) they attest to a mantle source already enriched in most of trace elements with a rather high fractionation between the most and the less incompatible elements and without any Ta and $\mathrm{Nb}$ depletion; or

(2) they attest to a very low partial melting degree of a mantle composition close to that of the primitive mantle.

When $\mathrm{Th}_{\mathrm{n}}$ and $\mathrm{MgO}$ are correlated with $\mathrm{Ni}$, Cr and $\mathrm{Th}_{\mathrm{n}} / \mathrm{Ta}_{\mathrm{n}}$ (figure 6), most of samples show fractional crystallization relationships, but partial melting relationships also exist between the richest samples in $\mathrm{Ni}$ and $\mathrm{Cr}$.

\subsubsection{Middle Triassic (T2) group}

On CH-normalized rare earth element spidergrams (figure 5), their patterns display an enrichment in the most incompatible $\left(\mathrm{La}_{\mathrm{n}} / \mathrm{Yb}_{\mathrm{n}}=2.8\right.$ to 3.7$)$, intermediate between those of OIB and E-MORB. On the PM-normalized trace element spidergrams (figure 5) negative anomalies, rather strong in Ta and $\mathrm{Nb}$ and moderate in $\mathrm{Ba}$ and $\mathrm{Ti}$, exist as well as a moderate positive anomaly in Sr. These features fit with a calc-alkaline affinity as defined with major elements. Their PM-normalized total trace element content (sumTE: 400 ppm in average; figure 6) is much lower than in the Late Devonian group. $\mathrm{Th}_{\mathrm{n}} / \mathrm{La}_{\mathrm{n}}$ (1.3 to 1.5 ), $\mathrm{La}_{\mathrm{n}} / \mathrm{Sm}_{\mathrm{n}}$ (1.6 to 1.8), $\mathrm{Sm}_{\mathrm{n}} / \mathrm{Zr}_{\mathrm{n}}$ (0.8 to 0.9 ) ratios are higher than in the Late Devonian group, whereas $\mathrm{Th}_{\mathrm{n}} / \mathrm{Yb}_{\mathrm{n}}$ (5 to 5.5), $\mathrm{La}_{\mathrm{n}} / \mathrm{Yb}_{\mathrm{n}}$ (3.4 to 3.7) and $\mathrm{Sm}_{\mathrm{n}} / \mathrm{Yb}_{\mathrm{n}}$ (1.9 to 2.15) ratios are less high.

Preliminary interpretations: As for the Late Devonian group, the source of these Middle Triassic (T2) volcanics could be located in the lithospheric mantle, the composition of which already included $\mathrm{Ta}$ and $\mathrm{Nb}$ anomalies and had a lower content in trace elements and a less high fractionation between the most and the less incompatible elements than for the Late Devonian group. Another hypothesis would be that currently invoked to explain the calc-alkaline feature of basic magmas. The source would be an asthenospheric residual mantle contaminated by partial melts generated during subduction of an oceanic lithosphere, these melts including $\mathrm{Ta}$ and $\mathrm{Nb}$ anomalies. As presented in Introduction, that geodynamic context is a priori precluded accounting for the great distance of the oceanic slab (600 km minimum) on the plate tectonics reconstruction (Adamia et al 1981; Gamkrelidze 1986; Zonenshain et al 1990; Stampfli et al 2001) and the tectono-sedimentary evolution itself of the Fore-Caucasus area.

Besides both partial melting and fractional crystallization trends can be defined among the Middle Triassic (T2) samples when $\mathrm{Th}_{\mathrm{n}}$ and $\mathrm{MgO}$ are correlated with $\mathrm{Ni}, \mathrm{Cr}$ and $\mathrm{Th}_{\mathrm{n}} / \mathrm{Ta}_{\mathrm{n}}$ (figure 6 ).

\subsubsection{Late Triassic (T3) group}

The two analyzed samples of this group, T3-A and T3-B, show really different $\mathrm{CH}-$ and PMnormalized patterns (figure 5). The fractionation between the most and less incompatible elements and the total trace element content (figure 6) are higher for T3-A and close to that of Late Devonian patterns, but rather low for T3-B and close to those of Middle Triassic (T2) patterns. However, the fractionations between the most incompatible elements are close to that in T2. Besides both samples display slight negative $\mathrm{Ta}$ and $\mathrm{Nb}$ anomalies, hardly more visible in T3-A $\left(\mathrm{Th}_{\mathrm{n}} / \mathrm{Ta}_{\mathrm{n}}=1.6\right)$ than in $\mathrm{T} 3-\mathrm{B}$ $\left(\mathrm{Th}_{\mathrm{n}} / \mathrm{Ta}_{\mathrm{n}}=1.1\right)$.

Preliminary interpretations: The similarities of trace element patterns, either with Late Devonian 

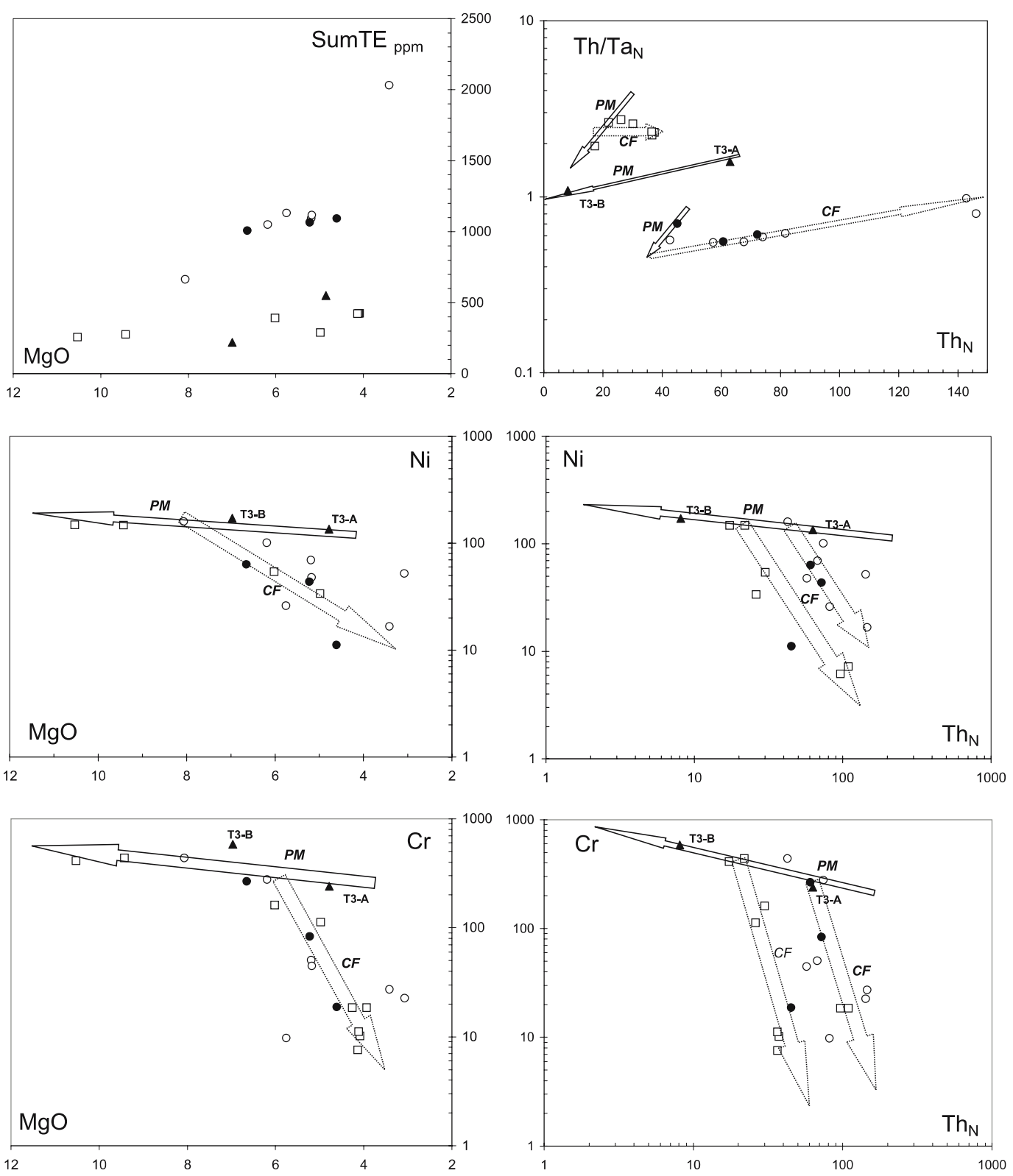

Figure 6. Variations of total trace element, $\mathrm{Ni}$ and $\mathrm{Cr}$ contents vs. $\mathrm{MgO}$; variations of $\mathrm{Th}_{\mathrm{n}} / \mathrm{Ta}_{\mathrm{n}}, \mathrm{Ni}, \mathrm{Cr}$ vs. Th $\mathrm{n}$. Same symbols as in figure 2: Possible Partial Melting (PM) and Fractional Crystallization (FC) trends. See text for explanation.

(D) or Middle Triassic (T2), as for the major elements, argue in favor a mantle source rather close in composition either with that of $\mathrm{D}$ or that of $\mathrm{T} 2$, thus located in the same mantle at large scale. This is also supported by the fact that T3-A and T3-B plot on the partial melting trend of both other groups (figure 6). So T3-A and T3-B would originate from successive and increasing melting of the same mantle source, and this mantle source had a global composition close to the source of the D or T2 basalts.

Summary of preliminary interpretations: Most of observations lead to think that a number of trace element features of both Late Devonian and
Triassic volcanic groups are source effects, clearly distinct from partial melting and fractional crystallization effects which are identified within each group. On the whole Late Devonian and Triassic volcanic groups show many common points but also some significant differences. In detail, Late Triassic (T3) appears to be transitional between Late Devonian (D) and Middle Triassic (T2). In that hypothesis, all the volcanics come from partial melting of distinct sources located within a same heterogeneous mantle, an already trace element enriched mantle with a ratio between the most and the less incompatible elements always above 1 . The D source differs from the T2 source in having a much higher total trace element content, a higher 
degree of fractionation between the most and the less incompatible elements, but a lower degree of fractionation between the highly incompatible elements themselves. The T3 source has intermediate features between both the two others. Besides Ta and $\mathrm{Nb}$ negative anomalies, absent in the $\mathrm{D}$ mantle source, are slight in the T3 mantle source but significant in the T2 mantle source. In each group, samples are genetically linked by partial melting and above all crystal fractionation processes. Both T3 samples could be representative of successive partial melts from a mantle source closer in terms of composition to the mantle source of D.

\subsection{Sr and Nd isotopic compositions}

$\mathrm{Rb}-\mathrm{Sr}$ and $\mathrm{Sm}-\mathrm{Nd}$ isotopic data (table 2) have been obtained on the two most primitive samples in each group. As Rb data obtained via inductive coupled plasma-mass spectrometer (ICP-MS) or isotopic dilution (ID) differ from each other, two distinct $\left({ }^{87} \mathrm{Sr} /{ }^{86} \mathrm{Sr}\right) \mathrm{i}$ ratios for each sample was calculated. The eruption times for each group are taken from McCann et al (2003) and Tikhomirov et al (2004). Nevertheless as the relative distribution of data from the three groups on the $\varepsilon N d i v s .\left({ }^{87} \mathrm{Sr} /{ }^{86} \mathrm{Sr}\right) \mathrm{i}$ diagram does not change depending on the used $\mathrm{Rb}$ value, the demonstration will be based on isotopic ratios using Rb ICP-MS values. The limited scattering of data for both Late Devonian (D) and Triassic (T) groups and the fact that they superpose in part to the isotopic data of Late Devonian basalts from the Pripyat-Dniepr-Donets (PDD) (Wilson and Lyashkevich 1996) rules out the possibility that the high ${ }^{87} \mathrm{Sr} /{ }^{86} \mathrm{Sr}$ ratio may reflect a leaching problem. Nevertheless for some data, a slight subhorizontal shift towards elevated ${ }^{87} \mathrm{Sr} /{ }^{86} \mathrm{Sr}$ due to secondary alteration cannot be excluded and it will be taken into account for the discussion about the Sr model age.

On the $\varepsilon$ Ndi vs. $\left({ }^{87} \mathrm{Sr} /{ }^{86} \mathrm{Sr}\right) \mathrm{i}$ diagram (figure $7 \mathrm{a}$ ), $\mathrm{D}$ and $\mathrm{T}$ basalts occupy a very restricted field within the north-east quadrant with $\varepsilon$ Ndi between +1.80 and +4.28 and $\left({ }^{87} \mathrm{Sr} /{ }^{86} \mathrm{Sr}\right) \mathrm{i}$ between 0.70434 and 0.70592 .

Our isotopic data partly superpose to the published isotopic data of Late Devonian mafic and ultramafic volcanics and subsurface intrusives from the same Pripyat-Dniepr-Donets megarift (in Wilson and Lyashkevich 1996). Also they totally superpose to those of Late Devonian kimberlites and melilitites from the Archangelsk region northwards (Mahotkin and Juravlev's data, 1993, in Wilson and Lyashkevich 1996). So our data are coherent with previously published ones. Also the ${ }^{87} \mathrm{Sr} /{ }^{86} \mathrm{Sr}$ subhorizontal shift, which could be assumed for our data, is likely slight.
Such initial isotopic values imply that they plot on mixing trends between depleted mantle (DM) and continental crust (CC) end-members. The crustal end member could be replaced by an enriched mantle (EM), already metasomatized by crustal material. Indeed positive $\varepsilon N$ di values inherent to most studied samples suggest a depleted mantle end-member, whereas higher than CHUR $\left({ }^{87} \mathrm{Sr} /{ }^{86} \mathrm{Sr}\right)_{\mathrm{i}}$ values suggest that this depleted mantle was metasomatized by melts or aqueous fluids with a dominant continental crust signature. The limited scattering of data of $\mathrm{D}$ and $\mathrm{T}$ groups can be explained by percolation, within a rather homogeneous depleted mantle (asthenosphere, as defined for the MORB source), of contaminant melts with similar isotopic ratios but with slightly different $\mathrm{Nd} / \mathrm{Sr}$ ratios and in different proportions (see Faure 1986 for explanations). This gave birth to small scale mantle heterogeneity, whereas D and T mantle sources $(200-300 \mathrm{~km}$ far from each other) could belong to a same mantle at large scale. In any case, the isotopic signatures are typical for a trace element enriched mantle as found in the continental lithospheric mantle (Wilson 1989; King and Anderson 1995; Wilson and Lyashkevich 1996; Chalot-Prat and Boullier 1997 and references therein; Furman and Graham 1999; Weinstein et al 2006 and references therein).

On a diagram illustrating the evolution of $\mathrm{Nd}$ isotopic composition of mantle sources for each sample (figure 7b), all trends cross the evolution line of the depleted mantle (Salters and Stracke 2004) within a rather straight age interval (around $650 \mathrm{Ma} \pm 50$; up to $850 \mathrm{Ma}$; early Neoproterozoic III). The evolution of the primitive mantle residue was thus disturbed during this period. The causes could be partial melting combined with, or followed by, major metasomatic events during this period. The evolution of the Sr isotopic compositions (figure 7c) gives a larger range of values (700 to $2700 \mathrm{Ma}$ ). They do not contradict the $\mathrm{Nd}$ model ages, but cannot be further discussed as $\mathrm{Rb}$ and $\mathrm{Sr}$ are believed to be much more mobile than the rare earth elements during alteration processes.

It is not excluded however that this contaminated mantle belonged to the much deeper low velocity transitional zone interlayered between the upper and the lower mantles and in which crust is continuously recycled (Ivanov and Balyshev 2005). This would fit with the hypothesis of Wilson and Lyashkevich (1996) for an origin of Late Devonian basalts from a deep mantle plume. This hypothesis about the very great mantle melting depth was based upon the parameterization of melting experiments on anhydrous mantle peridotite. It does not match with the temperature and lithospheric depth location of hydrous peridotite solidus in the Falloon and Green diagram (1990), as also underlined by 


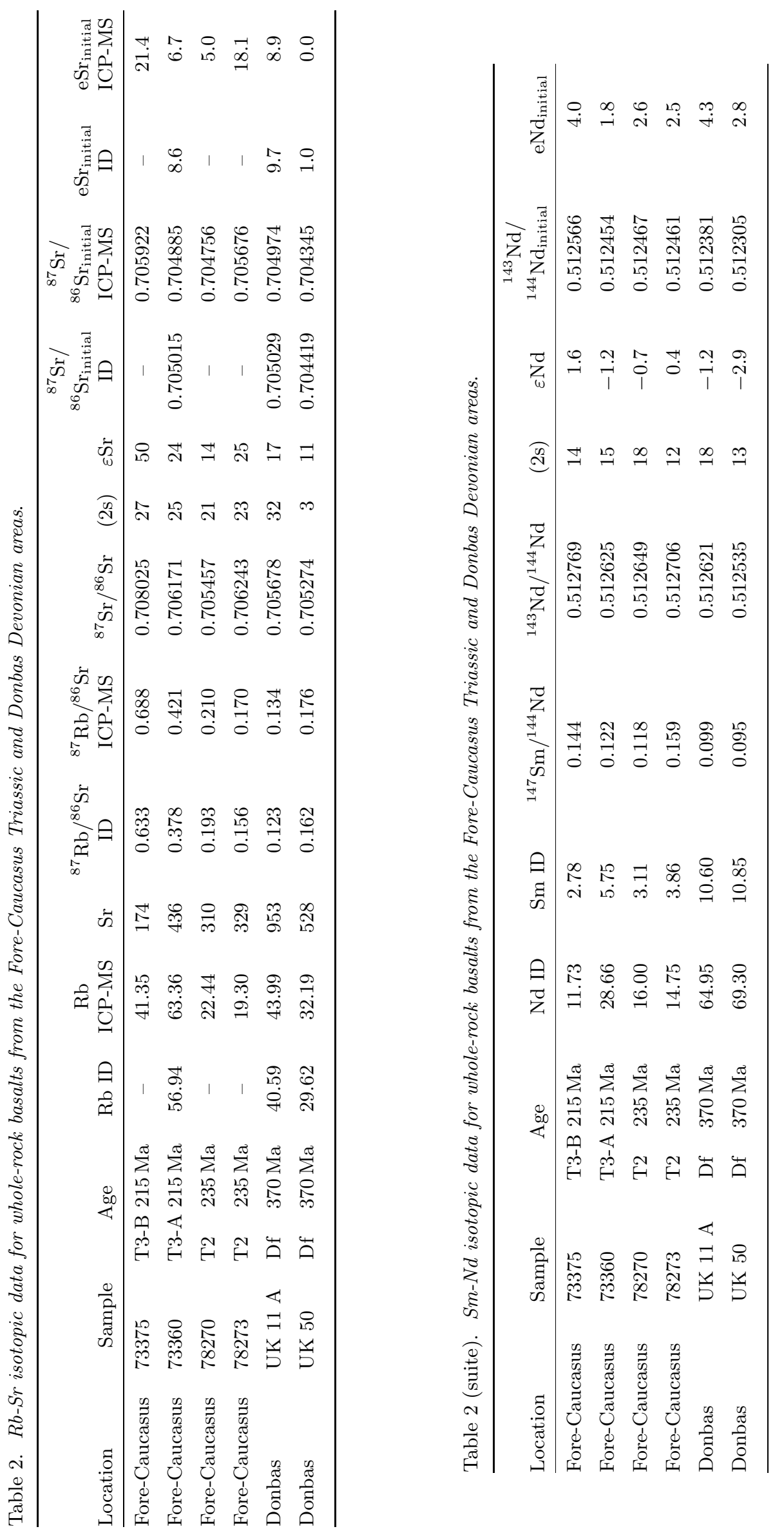



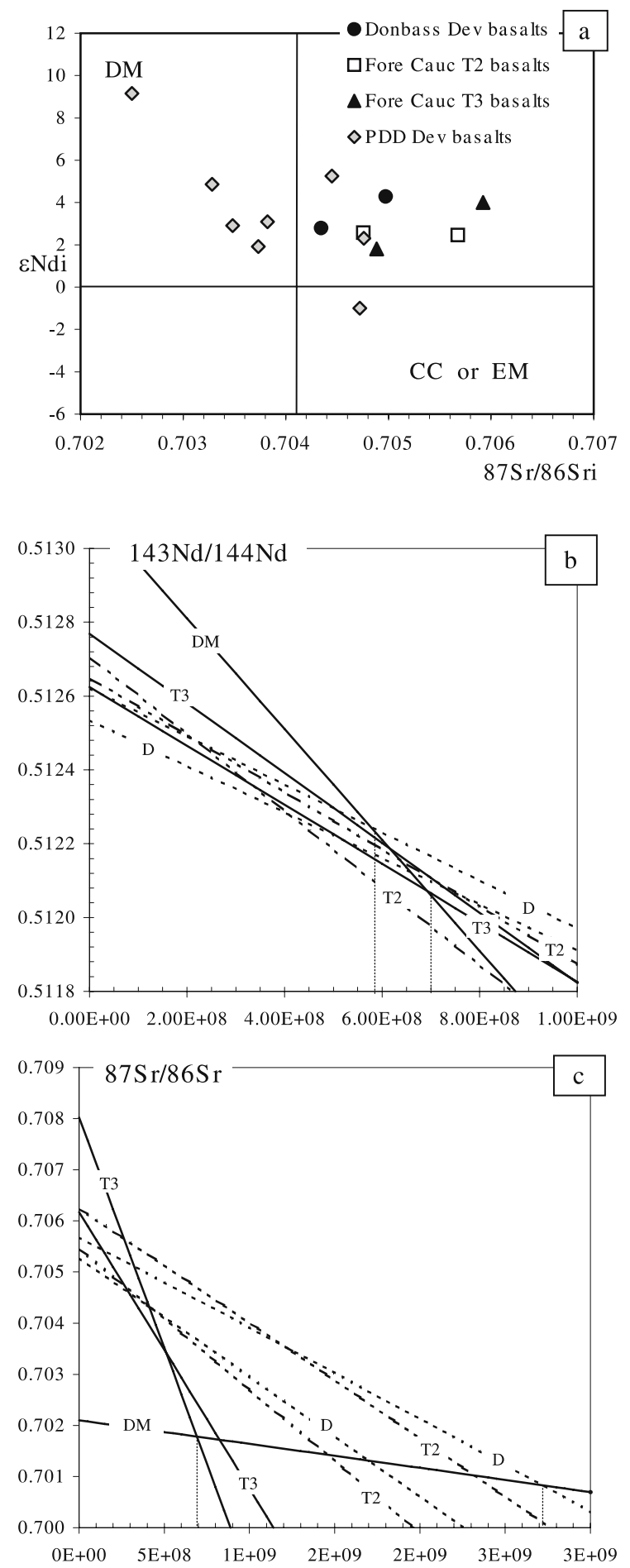

Figure 7. (a) Initial $\mathrm{Nd}$ and $\mathrm{Sr}$ isotopic signatures of Late Devonian (D), Middle (T2) and Late (T3) Triassic basalts; same symbols as in figure 2. Also plotted for comparison, the initial $\mathrm{Nd}$ and $\mathrm{Sr}$ isotopic signatures of the Late Devonian mafic and ultramafic rocks (Wilson and Lyashkevich 1996) from the same Pripyat-Dniepr-Donets mega-rift (PDD) than the D basalts. DM: depleted mantle; CC: continental crust; EM: enriched mantle. (b) Nd model ages for mantle sources of Late Devonian (D), Middle (T2) and Late (T3) Triassic basalts. (c) Sr model ages for mantle sources of Late Devonian (D), Middle (T2) and Late (T3) Triassic basalts. DM: Depleted Mantle with DM isotopic values after Salters and Stracke (2004). Vertical dotted lines in b and c indicate minimum and maximum model ages.
Wilson (1993). Also the exclusive involvement of the continental lithospheric mantle both for the $\mathrm{D}$ and $\mathrm{T}$ sources easily explains the similarity of the isotopic signatures of basaltic eruptions occurring after an interval of 110 to $150 \mathrm{Ma}$ and not so far from each other $(200-300 \mathrm{~km})$ on the East European Platform margin.

\section{Hypotheses in favor of mantle sources within the same continental lithosphere at the southern margin of the East European Platform}

As explained in the Introduction, the aim of our study is to improve our knowledge of the mantle below the southern margin of the Eastern European Platform at time of the Late Devonian and Triassic eruptions. Considering all observations gathered successively on the mantle magmas emplaced during each period, the main features of mantle sources can be summarized as follows.

From $\mathrm{Sr}$ and $\mathrm{Nd}$ isotopic signatures, the involved mantle is rather homogeneous on a large scale with a composition resulting from mixing between depleted mantle and continental crustal endmembers. According to its Nd isotopic evolution, this mantle was disturbed during the Early Neoproterozoic III (around $650 \pm 50 \mathrm{Ma}$ ) and thus recorded the same history on the whole. No trace of a Variscan event is detected. Mantle partial melting and/or only mantle metasomatism by percolation of crustal liquids could be the causes of this major disturbance. At small scale, slight compositional variations and proportions of both end-members involved during the mixing event gave birth to a heterogeneous metasomatized mantle like in any continental lithosphere.

From trace elements, the large-scale homogeneity concerns the high trace element content with a systematic positive ratio between the most and the less incompatible elements. The heterogeneity concerns:

- the total trace element contents, much lower in Triassic than in Late Devonian sources;

- the fractionation between the most and the less incompatible elements decreasing from Late Devonian (D) to Middle Triassic (T2) sources, the Late Triassic (T3) source having mixed features.

At last in the Triassic sources and above all in the $\mathrm{T} 2$ source, the $\mathrm{Ta}$ and $\mathrm{Nb}$ contents are lower than expected considering their high incompatibility degree during mantle partial melting. All these characteristics cannot originate from the trace element depleted mantle end-member, but from the composition of contaminant melts 
more or less trace element enriched and fractionated and specifically $\mathrm{Ta}$ - and $\mathrm{Nb}$-poor in the $\mathrm{T}$ sources. These melts, without or with $\mathrm{Ta}$ and $\mathrm{Nb}$ negative anomalies, could have come from partial melting of suboverthrusted slices of continental crust/metasomatized mantle during the last major orogenic event before eruptions, early Neoproterozoic III in age according the $\mathrm{Nd}$ model ages.

From major elements, the mantle was rich in alkali with a rather high alkali-silica ratio, which can be explained with the existence of mantle metasomatic amphibole and/or phlogopite and/or even diopside (Wilson 1989; Wilson and Downes 1991, 1992; Best and Christiansen 2001; Weinstein et al 2006 and references therein). Higher $\mathrm{TiO}_{2}$, $\mathrm{K}_{2} \mathrm{O}, \mathrm{P}_{2} \mathrm{O}_{5}$ and $\mathrm{FeO}$ contents in the Late Devonian mantle source mean necessarily a higher content of these elements in metasomatic minerals as phlogopite, diopside but also apatite, rutile and some other accessory minerals (Foley 1992; Chalot-Prat and Arnold 1999; Best and Christiansen 2001, and references therein).

The presence or not of $\mathrm{Ta}$ and $\mathrm{Nb}$ negative anomalies in Late Devonian and Triassic basic rocks being source effects, they were necessarily included in the metasomatic minerals, interstitial or in veins within the peridotite, and due to the signature of contaminant crustal melts (Lloyd et al 1985; Chalot-Prat and Boullier 1997; Pecerillo 1999, 2002; Pecerillo and Panza 1999; ChalotPrat and Girbacea 2000; Pecerillo et al 2001). This variety of mantle signatures at small scale is typical of the continental lithosphere (Johnson et al 1978; Wilson 1989; Foley 1992; Wilson and Downes 1991, 1992; Serri et al 1993; Smith 1993; ChalotPrat and Boullier 1997; Sheth 1999a, b; Best and Christiansen 2001; Neumann et al 2002; Pecerillo and Lustrino 2005).

The Eastern European Platform continental mantle, successively involved after an interval from 110-150 Ma in areas at least two/three hundred kilometers far from each other, has a common history of partial melting and metasomatism at least since the early Neoproterozoic III. As no trace of a Variscan event is detected, that would confirm that the Permian event was not related to plate collision but to crustal transtensional reactivation (Gaetani 2000; Saintot et al 2003, 2006), synchronous with widespread regional uplift affecting the southern margin of the Eastern European Platform (as the Priazov massif in Stovba and Stephenson 1999). This uplift brought to the surface the buried greenschist Paleozoic succession and was likely related to regional rifting as in the Donbas (Stovba and Stephenson 1999; Saintot et al 2003; Shymanovskyy et al 2004). In that case, the latest orogenic event of the Scythian Platform might have been the late Proterozoic Baikalian development of an accretionnary belt (Saintot et al 2006).

In such a model, the partial melting events of this continental mantle, synchronous with a major continental crust fracturing for magma ascent up to the surface, during Late Devonian then Triassic times were a response to the large-scale stretching and uplift of the continental lithosphere during the rifting phases, as already proposed in similar environments by other authors (Wilson and Downes 1992; Wilson 1993 and references therein; Anderson 1994; Sheth 1999a, b; ChalotPrat and Girbacea 2000). A mantle-crust decoupling, as considered by Chalot-Prat and Girbacea (2000) is a likely possibility. The melting would be induced by dramatic decompression of mantle just below the Моно discontinuity, whereas major but transient fractures would open throughout the continental crust to enable the magma to erupt at surface. This decoupling could also occur along rheological discontinuities within the heterogeneous lithospheric mantle itself, which would explain why mantle sources slightly varied in composition with time during the Triassic, and from the Late Devonian to the Triassic. Another explanation for triggering mantle melting during lithospheric extension could be shearing along the rheological discontinuities within the mantle (Doglioni et al 2005). Lithospheric plate motions relative to the underlying asthenosphere, according to the demonstrations of Doglioni (1990, 2003 and references therein), were likely the main motor of these decoupling/shearing and fracturing processes, while the rheological heterogeneity of the lithosphere and of the mantle itself helped to localize deformation and partial melting.

\section{Conclusions}

This comparative study of basic volcanics, emplaced after an interval of 110 to $150 \mathrm{Ma}$ in areas at least two/three hundred kilometers far from each other in distinct continental rifting contexts on the southern margin of the East European Platform, shows that alkaline and cal-alkaline basic magmas could originate from partial melting of a similar continental lithospheric mantle, heterogeneous at small scale.

From the major and trace element characteristics of the volcanics, the whole mantle source is supposed to have been more or less rich in alkali and $\mathrm{TiO}_{2}$, with a positive ratio between the most and the less incompatible trace element. These compositional features are known to come from melting of some main metasomatic mantle minerals 
such as amphibole and/or phlogopite and/or diopside and/or apatite and/or rutile, etc. The rather similar $\mathrm{Nd}$ and $\mathrm{Sr}$ isotopic signatures of volcanics of both ages match with that of a mantle-crust mixing source such as the continental metasomatized mantle. The crustal component could have come from either continental crust (old oceanic crust?) or already metasomatized mantle typeEMII, while the mantle component was a residue after melting of the Primitive Mantle. From the Nd model ages, the youngest major event (with metasomatism at least) recorded by the mantle sources occurred about $650 \pm 50 \mathrm{Ma}$ ago, a long time before both Late Devonian and Triassic eruptions.

In detail, the Late Devonian mantle source differs from the Triassic mantle sources by its higher alkali-silica ratio, its higher $\mathrm{TiO}_{2}, \mathrm{~K}_{2} \mathrm{O}, \mathrm{P}_{2} \mathrm{O}_{5}$ and $\mathrm{FeO}$ contents, the lower fractionation between the most incompatible elements, the higher fractionation between the most and the less incompatible elements and the absence of $\mathrm{Ta}$ and $\mathrm{Nb}$ negative anomalies. These differences are linked to the type, the composition and the proportion of metasomatic mantle minerals, themselves dependent on both the composition and volume of the contaminant melts injected within the mantle during the last major orogenic event at least.

So the Late Devonian and Triassic eruptions, registered within tectono-sedimentary events after an interval of $110-150 \mathrm{Ma}$ and in areas at least two-three hundred kilometers far from each other, involved the continental lithospheric mantle which underlay the southern continental margin of the East European Platform. The causes of mantle melting and magma eruptions are believed to be a direct consequence of plate motions. They are attributed to decoupling and/or shearing along the rheological discontinuities between crust and mantle or even within the lithospheric mantle itself, associated to a major but transient fracturing of the overlying continental lithosphere.

\section{Acknowledgements}

The study was carried on in the framework of EUROPROBE's Georift/INTAS 97-0743 project. PT warmly thanks the CRPG for their welcome and all the facilities he benefited from as a visitor scientist during spring seasons of 2001 and 2002. FCP and PT sincerely thank Laurie Reisberg and Catherine Spatz for helping PT to perform the Sm$\mathrm{Nd}$ and Rb-Sr isotopic analysis at CRPG/CNRS and for help in reducing and finalizing the data. We are very grateful to H Sheth and R Stephenson for their pertinent remarks and constructive reviews of a preliminary version of the manuscript.
Reviews by A Ivanov and an anonymous reviewer were of great help. This is the CRPG contribution $n^{\circ} 1694$.

\section{References}

Adamia S A, Chkhouta T, Kekelia M, Lordkipanidze M B, Shavishvili I D and Zakariadze G S 1981 Tectonics of the Caucasus and adjoining regions: implications for the evolution of the Tethys ocean; J. Struct. Geol. 3(4) 437-447.

Adamia Sh A and Lordkipanidze M B 1989 An outline of Georgian Geological Structure; In: Evolution of the northern margin of Tethys (eds) Rakuš M, Dercourt J and Nairn A E M, IGCP project $\mathrm{n}^{\circ} 198$ Mém. Soc. Géol. France, Paris Nouvelle Série 154 II 63-66.

Alekseev A S, Kononova L I and Nikishin A M 1996 The Devonian and Carboniferous of the Moscow Syneclise (Russian Platform): stratigraphy and sea-level changes; In: EUROPROBE: Intraplate Tectonics and Basin Dynamics of the Eastern European Platform; (eds) Stephenson R A, Wilson M, De Boorder H and Starostenko V I, Tectonophys. 268 149-168.

Anderson D L 1994 The sublithospheric mantle as the source of continental flood basalts; the case against the continental lithosphere and plume head reservoirs; Earth Planet. Sci. Lett. 123 269-280.

Artemieva I M 2003 Lithospheric structure, composition, and thermal regime of the East European Craton: implications for the subsidence of the Russian platform; Earth Planet. Sci. Lett. 213(3-4) 431-446.

Arthaud F and Matte P 1977 Late Paleozoic strike-slip faulting in southern Europe and northern Africa; result of a right-lateral shear zone between the Appalachians and the Ural; Geol. Soc. Amer. Bull. 88(9) $1305-1320$.

Belov A A 1981 Tectonic Development of the Alpine Fold Area in the Paleozoic, Nauka, Moscow (in Russian).

Best M G and Christiansen E H 2001 Igneous Petrology; Blackwell Science, 458 pp.

Bogdanova S V, Pashkevich I K, Gorbatschev R and Orlyuk M I 1996 Riphean rifting and major Palaeoproterozoic crustal boundaries in the basement of the East European Craton: geology and geophysics; Tectonophys. 368 1-21.

Burshtar M S, Myshkova Yu F and Shvemberger Yu N 1973 Sedimentary-volcanic complex (Upper TriassicLower Jurassic) of the East Fore-Caucasus, and perspectives of its oil and gas productivity; Litologiya $i$ poleznye iskopaemye 6 58-67 (in Russian).

Brown D, Juhlin C, Alvarez-Marron J, Perez-Estaun A and Oslianski A 1998 Crustal-scale structure and evolution of an arc-continent collision zone in the Southern Urals; Russia; Tectonics 17(2) 158-171.

Brown D and Spadea P 1999 Processes of forearc and accretionary complex formation during arc-continent collision in the Southern Ural Mountains; Geology (Boulder) 27(7) 649-652.

Brown D, Juhlin C and Puchkov V (eds) 2002 Mountain Building in the Uralides: Pangea to the Present; AGU publications, Geophysical Monograph Series 132288 pp.

Chalot-Prat F and Boullier A M 1997 Metasomatic events in the subcontinental mantle beneath the Eastern Carpathians (Romania): new evidences from trace elements; Contrib. Mineral. Petrol. 129 284-307.

Chalot-Prat F and Arnold M 1999 Immiscibility between calcio-carbonatitic and silicate melts and related wall rock reactions in the upper mantle: a natural case 
study from Romanian mantle xenoliths; Lithos 46(4) 627-659.

Chalot-Prat F and Girbacea R 2000 Partial delamination of continental mantle lithosphere, uplift-related crustmantle decoupling, volcanism and basin formation: a new model for the Pliocene-Quaternary evolution of the southern East-Carpathians, Romania; Tectonophys. 327 83-107.

Chekunov A V, Vecelov A A and Guilkman A I 1976 Structural geology and history of Black Sea basin development; Kiev, Naukova Dumka, 163 pp (in Russian).

Chekunov A V and Naumenko V V 1982 Relationship between the Earth's crust's deep rearrangement, tectonic movements, magmatism, metamorphism and metal content in the Dniepr-Donets Paleorift; J. Geophys. 4 $25-34$.

Chekunov A V, Garvish V K, Kutas R I and Ryabchun L I 1992 Dniepr-Donets palaeorift; Tectonophys. 208(1-3) 257-272.

Chekunov A V, Kaluzhnaya L T and Ryabchun L I 1993 The Dniepr-Donets paleorift, Ukraine, deep structures and hydrocarbon accumulations; J. Petroleum Geology 16 183-196.

Chirvinskaya M V and Sollogub V B 1980 Deep structure of the Dniepr-Donets Aulacogen from geophysical data; Naukova Dumka, Kiev, 178 pp. (in Russian).

Dercourt J, Ricou L-E and Vrielynck B 1993 Atlas Tethys, Palaeoenvironmental maps; Gauthier-Villars, Paris, 307, 14 maps, $1 \mathrm{pl}$ and explanatory notes.

Dercourt J, Gaetani M, Vrielynck B, Barrier E, BijuDuval B, Brunet M F, Cadet J P, Crasquin S and Sandulescu M 2000 Atlas Peri-Tethys, Palaeogeographical maps; CCGM/CGMW Paris 26924 maps and explanatory notes.

Doglioni C 1990 The global tectonic pattern; J. Geodynamics 12(1) 21-38.

Doglioni C, Harabaglia P, Merlini S, Mongelli F, Peccerillo A and Piromallo C 1999 Orogens and slabs vs. their direction of subduction; Earth-Sci. Rev. 45 167-208.

Doglioni C 2003 Rift asymmetry and continental uplift; Tectonics 22(3) 1-13.

Doglioni C, Green D H and Mongelli F 2005 On the shallow origin of hotspots and the westward drift of the lithosphere; In: Plates, Plumes, and Paradigms (eds) Foulger G R, Natland J H, Presnall D C and Anderson D L, Geological Society of America Special Paper $\mathbf{3 8 8}$ $735-749$

Dubinski A Ya and Matsenko N A 1965 Volcanosedimentary sequence in the basement of the sedimentary cover of the Scythian Platform eastern part; Sovetskaiya Geologiya 8 151-157 (in Russian).

Falloon T and Green D H 1990 Solidus of carbonated fertile peridotite under fluid-saturated conditions; Geology 18 195-199.

Faure G 1986 Principles of isotope geology (New York: John Wiley \& Sons) 589 pp.

Foley S 1992 Vein-plus-wall-rock melting mechanisms in the lithosphere and the origin of potassic alkaline magmas; Lithos 28 435-453.

Furman T and Graham D 1999 Erosion of lithospheric mantle beneath the East African Rift system: geochemical evidence from the Kivu volcanic province; Lithos $\mathbf{4 8}$ $237-262$

Gaetani M 2000 Wordian; In: Atlas Peri-Tethys, Palaeogeographical maps - Explanatory notes, S. Crasquin (coord.), CCGM/CGMW Paris 19-25.

Gamkrelidze I P 1986 Geodynamic evolution of the Caucasus and adjacent areas in Alpine time; Tectonophys. 127 261-277.
Glasmacher U A, Reynolds P, Alekseyvev A A, Puchkov V N, Taylor K, Gorozhanin V and Walter R $1999{ }^{40} \mathrm{Ar} /{ }^{39} \mathrm{Ar}$ thermochronology west of the Main Uralian fault, southern Urals, Russia; Geologische Rundschau 87 515-525.

Grigorieva V A, Kamenetsky A E, Pavlyuk M I, Palinscky R V and Plakhotny L G 1981 Formations and oil and gas potential of the Cretaceous sediments of the southern Ukraine; Kiev, Naukova Dumka, 140 pp (in Russian).

Ivanov A V and Balyshev S O 2005 Mass flux across the lower-upper mantle boundary: vigorous, absent, or limited? In: Plates, Plumes, and Paradigms (eds) Foulger G R, Natland J H, Presnall D C, Anderson D L, Geological Society of America Special Paper 388 327-346.

Johnson R W, Mackensie D E and Smith I E M 1978 Delayed partial melting of subduction-modified mantel in Papua New Guinea; Tectonophys. 46 197-216.

Khain V E 1975 Structure and main stages in the tectonomagmatic development of the Caucasus: an attempt at the geodynamic interpretation; American Journal of Science 275-A 131-156.

King D L and Anderson D L 1995 An alternative mechanism of flood basalt formation; Earth Planet. Sci. Lett. 136 269-279.

Le Maitre R W (ed.) 1989 A classification of igneous rocks and glossary of terms; Oxford, Blackwell Scientific.

Leschukh R Y 1992 Lower Cretaceous of the western and southern Ukraine; Naukova Dumka, Kiev, 208 pp (in Russian).

Letavin A I 1980 Basement of the Young Platform of the Southern Part of the USSR; Nauka Moscow, 153 pp (in Russian)

Lightfoot P C, Hawkesworth C J, Devey C W, Rogers N W and Van Calsteren P W C 1990a Source and differentiation of Deccan Trap lavas: implications of geochemical and mineral chemical variations; J. Petrol. 31(5) $1165-1200$.

Lightfoot P C, Naldrett A J, Gorbachev N S, Doherty W and Fedorenko V A 1990b Geochemistry of the Siberian Trap of the Noril'sk area, USSR, with implications for the relative contributions of crust and mantle to flood basalt magmatism; Contrib. Mineral. Petrol. 104 631-644.

Lloyd F E, Arima M and Edgar A D 1985 Partial melting of a phlogopite-clinopyroxenite nodule from south-west Uganda: an experimental study bearing on the origin of highly potassic continental rift volcanics; Contrib. Mineral. Petrol. 91 321-329.

Lordkipanidze M B, Meliksetian B and Djarbashian R 1989 Mesozoic-Cenozoic Magmatic Evolution of the Pontian-Crimean-Caucasian Region; In: Evolution of the northern margin of Tethys (eds) Rakuš M, Dercourt J and Nairn A E M, IGCP project $\mathrm{n}^{\circ} 198 ;$ Mémoire Société Géologique France, Paris, Nouvelle Série 154(II) 103-124.

McCann T, Saintot A, Chalot-Prat F, Kitchka A, Fokin P, Alekseev A and EUROPROBE-INTAS RESEARCH TEAM 2003 Evolution of the southern margin of the Donbass (Ukraine) from Devonian to Early Carboniferous times; In: Tracing Tectonic Deformation Using the Sedimentary Record (eds) McCann T and Saintot A, Geol. Soc. London Spec. Publ. 208 117-135.

Milanovsky E E 1996 Geology of Russia and Adjacent Areas (Northern Eurasia); Moscow University Press, Moscow, 448 pp (in Russian).

Muratov M V 1969 Geology of the USSR. Volume VIII, Crimea. Part 1, Geology, Nedra, Moscow, 576 pp (in Russian)

Nazarevich P B, Nazarevich I A and Shvydko N I 1986 The Upper Triassic Nogai volcano-sedimentary formation 
of Eastern Fore-Caucasus: composition, constitution, and relations to earlier- and later-formed volcanics; In: The formations of sedimentary basins (eds) Timofeev P P and Boulin $\mathrm{Yu}$ K, Moscow, 67-86 (in Russian).

Neumann E-R, Dunworth E A, Sundvoll B A and Tollefsrud J I 2002 B1 basaltic lavas in Vestfold-Jeloya area, central Oslo rift: derivation from initial melts formed by progressive partial melting of an enriched mantle source; Lithos 61 21-53.

Nikishin A M, Ziegler P A, Stephenson R A, Cloetingh S A P L, Furne A V, Fokin P A, Ershov A V, Bolotov S N, Korotaev M V, Alekseev A S, Gorbachev V I, Shipilov E V, Lankreijer A, Bembinova E Yu and Shalimov I V 1996 Late Precambrian to Triassic history of the East European Craton: dynamics of sedimentary basin evolution; Tectonophys. 268 23-63.

Nikishin A M, Cloetingh S A P, Bolotov S N, Baraboshkin E Yu, Kopaevich L F, Nazarevich B P, Panov D I, Brunet M-F, Ershov A V, Il'ina V V, Kosova S S and Stephenson R A 1998a Scythian platform, Chronostratigraphy and polyphase stage of tectonic history; In: Stratigraphy and Evolution of the Peri-Tethyan Platforms (eds) Crasquin-Soleau S and Barrier E, Peri-Tethys Memoir 3 Memoires du Museum National d'Histoire Naturelle Paris 177 151-162.

Nikishin A M, Cloetingh S A P L, Baraboshki E Yu, Bolotov S N, Kopaevich L F, Nazarevich B P, Panov D I, Brunet M-F, Ershov A V, Kosova S S, Il'ina V V and Stephenson R A 1998b Scythian platform, Caucasus and Black Sea region: Mesozoic-Cenozoic tectonic history and dynamics; In: Stratigraphy and Evolution of the Peri-Tethyan Platforms (eds) CrasquinSoleau S and Barrier E, Peri-Tethys Memoir 3 Memoires du Museum National d'Histoire Naturelle Paris $\mathbf{1 7 7}$ 163-176.

Nikishin A M, Ziegler P A, Panov D I, Nazarevich B P, Brunet M-F, Stephenson R A, Bolotov S N, Korotaev M V and Tikhomirov P L 2001 Mesozoic and Cenozoic evolution of the Scythian Platform-Black SeaCaucasus domain; In: Peri-Tethyan Rift/Wrench Basins and Passive Margins (eds) Ziegler $\mathrm{P}$ A, Cavazza W, Robertson A H F and Crasquin-Soleau S, Peri-Tethys Memoir 6 Memoires du Museum National d'Histoire Naturelle Paris.

Pecerillo A 1999 Multiple mantle metasomatism in centralsouthern Italy: geochemical effects, timing and geodynamic implications; Geology 27(4) 315-318.

Pecerillo A 2002 Plio-Quaternary magmatism in centralsouthern Italy: a new classification scheme for volcanic provinces and its geodynamic implications; Bulletin Society Geologica Italiana 1 113-127.

Pecerillo A and Lustrino M 2005 Compositional variations of Plio-Quaternary magmatism in the circum-Tyrrhenian area: Deep versus shallow mantle processes; In: Plates, Plumes, and Paradigms (eds) Foulger G R, Natland J H, Presnall D C, Anderson D L, Geological Society of America Special Paper 388 421-434.

Pecerillo A and Panza G F 1999 Upper mantle domains beneath central-southern Italy: petrological, geochemical and geophysical constraints; Pure and Applied Geophysics 156 421-443.

Pecerillo A, Poli G and Donati C 2001 The plio-quaternary magmatism of southern Tuscany and northern Latium: compositional characteristics, genesis and geodynamic significance; Ofioliti 26(2a) 229-238.

Polovinkina Yu I 1960 Magmatisme mésozoïque et cénozoïque (tome II fascicule 4); In: (ed.) Markovsky A P Structure géologique de l'URSS, Paris, CNRS (Moscow, 1958) 2(4).
Puchkov V N 1997 Structure and geodynamics of the Uralian orogen; In: Orogeny trough times (eds) Burg J-P and Ford M, Geological Society Special Publication 121 201-236.

von Raumer J F, Stampfli G M and Bussy F 2003 Gondwana-derived microcontinents - the constituents of the Variscan and Alpine collisional orogens; Tectonophys. 365 7-22.

Saintot A, Stephenson R, Brem A, Stovba S and Privalov V 2003 Paleostress field reconstruction and revised tectonic history of the Donbas fold and thrust belt (Ukraine and Russia), Tectonics 22(5) 1059, doi:10.1029/2002TC001366.

Saintot A, Stephenson R, Stovba S, Brunet M-F, Yegorova T and Starostenko V 2006 The south margin of the East European continent: its evolution during the Palaeozoic and Early Mesozoic; In: European Lithosphere Dynamics (eds) Gee D and Stephenson R, Memoir of the Geological Society of London, London 32 482-505.

Saintot A, Brunet M-F, Yakovlev F, Sébrier M, Stephenson R, Ershov A, Chalot-Prat F and McCann T 2006 The Mesozoic-Cenozoic tectonic evolution of the Greater Caucasus; In: European Lithosphere Dynamics (eds) Gee D and Stephenson R, Memoir of the Geological Society of London, London 32 277-289.

Salters V J M and Stracke A 2004 Composition of the depleted mantle; Geochemistry, Geophysics, Geosystems 55.

Serri G, Innocenti F and Manetti P 1993 Geochemical and petrological evidence of the subduction of delaminated Adriatic continental lithosphere in the genesis of the Neogene-Quaternary magmatism of central Italy; Tectonophys. 223 117-147.

Sheth H C 1999a A historical approach to continental flood basalt volcanism: insights into pre-volcanic rifting, sedimentation, and early alkaline magmatism; Earth Planet. Sci. Lett. 168 19-26.

Sheth H C 1999b Flood basalts and large igneous provinces from deep mantle plumes: fact, fiction, and fallacy; Tectonophys. 311 1-29.

Shymanovskyy V A, Sachsenhofer R F, Izart A and Li Y 2004 Numerical modelling of the thermal evolution of the northwestern Dniepr-Donets Basin (Ukraine); Tectonophys. 381 61-79.

Smith A 1993 The continental mantle as a source for hotspot volcanism; Terra Nova 5 452-460.

Stampfli G, Mosar J, Faure P, Pillevuit A and Vannay J-C 2001 Permo-Mesozoic evolution of the Western Tethys realm, the Neotethys East Mediterranean basin connection; In: Peri-Tethyan Rift/Wrench Basins and Passive Margins (eds) Ziegler P, Cavazza W, Robertson A H F, Crasquin-Soleau S; Peri-Tethys Memoir 6, Memoires du Museum National d'Histoire Naturelle 186 51-108.

Stampfli G and Borel G D 2002 A plate tectonic model for the Paleozoic and Mesozoic constrained by dynamic plate boundaries and restored synthetic oceanic isochrons; Earth Planet. Sci. Lett. 196 17-33.

Stephenson R A \& the Europrobe Intraplate Tectonics and Basin Dynamics Dniepr-Donets and Polish Trough Working Groups 1993 Continental rift development in Precambrian and Phanerozoic Europe: EUROPROBE and the Dniepr-Donets Rift and Polish Trough basins; Sedim. Geol. 86 159-175.

Stephenson R A, Mart Y, Okay A, Robertson A, Saintot A, Stovba S and Khriachtchevskaia O 2004 TRANSMED Transect VIII: Eastern European Craton - Crimea Black Sea - Anatolia - Cyprus - Levant Sea - Sinai Red Sea; In: The TRANSMED Atlas: The Mediterranean 
Region from Crust to Mantle (eds) Cavazza W, Roure F, Spakman W, Stampfli G M and Ziegler P A (Berlin: Springer-Verlag).

Stephenson R A, Yegorova T, Brunet M-F, Stovba S, Wilson M, Starostenko V, Saintot A and Kusznir N 2006 Late Palaeozoic intra- and pericratonic basins on the East European Craton and its margins; In: European Lithosphere Dynamics; Gee D and Stephenson R (eds) Geological Society London Memoir 32 463-479.

Stovba S M and Stephenson R A 1999 The Donbas Foldbelt: its relationships with the uninverted Donets segment of the Dniepr-Donets Basin, Ukraine; Tectonophys. 313(1-2) 59-83.

Stovba S M, Stephenson R A and Kivshik M 1996 Structural features and evolution of the Dniepr-Donets Basin, Ukraine, from regional seismic reflection profiles; In: Intraplate Tectonics and Basin Dynamics of the Eastern European Platform (eds) Stephenson R A, Wilson M, De Boorder H and Starostenko V I, EUROPROBE: Tectonophys. 268 127-147.

Stovba S M and Stephenson R A 2002-2003 Style and timing of salt tectonics in the Dniepr-Donets Basin (Ukraine): implications for triggering and driving mechanisms of salt movement in sedimentary basins; Marine and Petroleum Geology 19 1169-1189.

Tikhomirov P, Chalot-Prat F and Nazarevitch B P 2004 Triassic Volcanism in the Eastern Fore-Caucasus: Evolution and Geodynamic Interpretation; Tectonophys. $\mathbf{3 8 1}$ $119-142$.

Torsvik T and Rehnström E F 2001 Cambrian palaeomagnetic data from Baltica: implications for true polar wander and Cambrian palaeogeography; J. Geol. Soc. London 158(2) 321-329.

Volozh Yu A, Antipov M P, Brunet M-F, Garagash I A, Lobrovsky L I and Cadet J-P 2003 Pre-Mesozoic geodynamics of the Peri-Caspian Basin (Kazakhstan); Sedim. Geol. 156 35-58.

Weinstein Y, Navon O, Altherr R and Stein M 2006 The role of lithospheric mantle heterogeneity in the generation of Plio-Pleistocene alkali basaltic suites from NW Harrat Ash Shaam (Israel); J. Petrol. 47(5) 1017-1050.

Wilson M 1989 Igneous Petrogenesis: a global tectonic approach, Unwin Hyman, London, 466 pp.

Wilson M 1993 Magmatism and the geodynamics of basin formation; Sedim. Geol. 86 5-29.

Wilson M and Downes H 1991 Tertiary-Quaternary extension-related alkaline magmatism in Western and Central Europe; J. Petrol. 32(4) 811-849.

Wilson M and Downes H 1992 Mafic alkaline magmatism associated with the European Cenozoic rift system; Tectonophys. 208 173-182.

Wilson M and Lyashkevich Z M 1996 Magmatism and the geodynamics of rifting of the Pripyat-DnieprDonets rift, East European Platform; Tectonophys. 268 65-81.

Ziegler P A 1990 Geological Atlas of Western and Central Europe. $2^{\text {nd }}$ edn. Shell International Petroleum, Mij. B.V., Geological Society of London, 239 pp.

Zonenshain L P, Kuzmin M I and Natapov L M 1990 Geology of the USSR: a plate tectonics synthesis (ed.) Page B M, American Geophysical Union, Washington DC, Geophysics Geodynamics Series 21242 pp. 